\title{
Debris flow sediment control using multiple herringbone water- sediment separation structures
}

\author{
XiangpingXie ${ }^{1,2}$, Fangqiang $\mathrm{Wei}^{3}$, Xiaojun Wang ${ }^{1}$, Hongjuan Yang ${ }^{1}$, James S. Gardner ${ }^{4}$
}

${ }^{1}$ Institute of Mountain Hazards and Environment/Key Laboratory of Mountain Hazards and Earth Surface Process,

${ }^{2}$ University of Chinese Academy of Sciences, Beijing 100049, China

${ }^{3}$ Chongqing Institute of Green and Intelligent Technology, Chinese Academy of Science,Chongqing, 400714, China

${ }^{4}$ Clayton Riddell Faculty of Environment, Earth and Resources, University of Manitoba, Canada

Correspondence to: Fangqiang Wei (fqwei@imde.ac.cn)

Abstract: Single herringbone water-sediment separation structures (HWSS) have limited sediment control effectiveness in debris flows. A series of such structures in a debris flow channel to form a multiple structure system (MHWSS system) should be more effective in debris flow mitigation. Hydraulic model tests reveal that a M-HWSS system does perform better in coarse sediment separation and has better stability in differing debris flow situations. The mean particle size of discharged sediment is gradually and significantly decreased down channel by M-HWSS system. The separated sediments are moderately sorted and this can be improved by optimizing the structure design parameters and increasing structure numbers. The fraction separation ratio $\left(\lambda_{i}\right)$, coarse separation ratio $\left(\lambda_{c}\right)$ and total sediment separation rate $\left(P_{\mathrm{t}}\right)$ are suggested parameters to express the sediment control effectiveness. All are closely related to the herringbone opening width and the input sediment grain size distribution. The quantitative relationships among them are proposed. On the basis of the tests, conclusions and guidelines for effective M-HWSS design include: 1) three structures in the M-HWSS located in succession upstream, midstream and downstream, each with substantially different in sediment control functions, 2) a structure's performance is strongly influenced by that of the preceding one so that every structure is designed to fully implement the sediment control function, especially for those in the upstream and midstream,3)the suggested herringbone opening width in a structure should be set at the percentile of $d_{50} \sim d_{84}$ of the input sediment grain size distribution so that $20 \sim 60 \%$ of the effective separation rate can be achieved.

Keywords: debris flow, sediment control, water-sediment separation structure, debris flow defense, multistage structures

\section{Introduction}

Many open-type damshave been developed and proved effective for debris flow mitigation.These include slit dams, beam dams, grid dams, debris breakers and flexible barriers(Armaniniet al.,1991;Wehrmann,et al.,2006;Armaniniet 
Nat. Hazards Earth Syst. Sci. Discuss., doi:10.5194/nhess-2016-340, 2016

Manuscript under review for journal Nat. Hazards Earth Syst. Sci.

Published: 25 October 2016

(c) Author(s) 2016. CC-BY 3.0 License.
Natural Hazards

and Earth System

Sciences

Discussions

(c) (i)

waterthrough physicalor hydrodynamic sorting to reduce debris flow discharge and intercept potentially damagingdebris. In so doing, they have been an improvement on solid check dams (Armanini et al., 1991). Although open-type dams are designed to be self-cleaning (Armanini et al.,1991; Mizuyama, 2008), clogging bylargebouldersand/or woody debris is often observed to hinder thewater-sediment separation function causinga back water effect (Mizuyama, 2008).To address this

5 problem,, a herringbone water-sediment separation structure (HWSS) was developed and testedby Xie Tet al.(2014). It's effectiveness in coarse debris separation and sediment control with less probability of clogging was verified through hydraulic model experiments (XieT et al.,2014;Xie XPet al., 2014,2016).

Field experience indicates that check dams of any type constructed in a series are most effective in mitigating the damaging effects of complex and high magnitude debris flows (VanDine, 1996). Many such systems have been put into

10 practice with relatively little prior research and testing of mitigation effects, with some exceptions (e.g. Ostiet al.,2008; Mouri,2013; Kimet al., 2014).In this paper, the conceptual background, design and model test results for a multiple herringbone water-sediment separation (M-HWSS) system are presented and discussed.

\section{The Concept of a M-HWSS system}

A M-HWSS system consists of a series of single HWSSs placed from upstream to downstream in a debris flow 15 transportation zone. Each HWSS includes a herringbone water-sediment separation grid with a solid sediment diversion dam leading into the grid (Fig.1). A system made up of $n$ HWSSs is denoted as an-HWSS system herein after. Xie T. et al. (2014) demonstrated that a single HWSS with a specific grid opening width $(D)$ can separate about $80 \%$ of the coarse sediment larger than the design size and a small amount of sediment finer than the design size. The proposed M-HWSS system employs a successive decrease of grid opening width $\left(D_{i}\right)$ from upstream to downstream structures to gradually separate

20 coarse debris(particles greater than $D_{\mathrm{i}}$ ) transported by a debris flow and store the separated sediment in corresponding bilateral deposit fields. The remaining fine sediment and water is discharged downstream through the structure outflow channel. The expected function of this M-HWSS system is sediment control through sorting and trapping, transforming debris flows into sediment-laden water flows. The debris flow impact pressures, total flow volumes and peak discharges will be substantially reduced through the separation of larger caliber sediment and other debris. The separated sediment will be

25 artificially removed from the deposit fields to maintain the mitigative capacity of the M-HWSS system. A secondary benefit of the progressive sorting will be ready availability of this material for building purposes.

Many debris flow variables, including magnitude or volume, maximum discharge and flow depth, debris particle size distribution, probable flow path(s), and impact pressures, must be taken into consideration in the design of control structures (Van Dine, 1996). Forthe M-HWSS system design, consideration of these variables is necessary for determining the number

30 of structures required for a specific debris flow location. Economic factors and specific channel topographic characteristics also must be considered in the determination of the number of structures. 
Nat. Hazards Earth Syst. Sci. Discuss., doi:10.5194/nhess-2016-340, 2016

Manuscript under review for journal Nat. Hazards Earth Syst. Sci.

Published: 25 October 2016

(c) Author(s) 2016. CC-BY 3.0 License.

(c) (i)
Natural Hazards

and Earth System

Sciences

Discussions

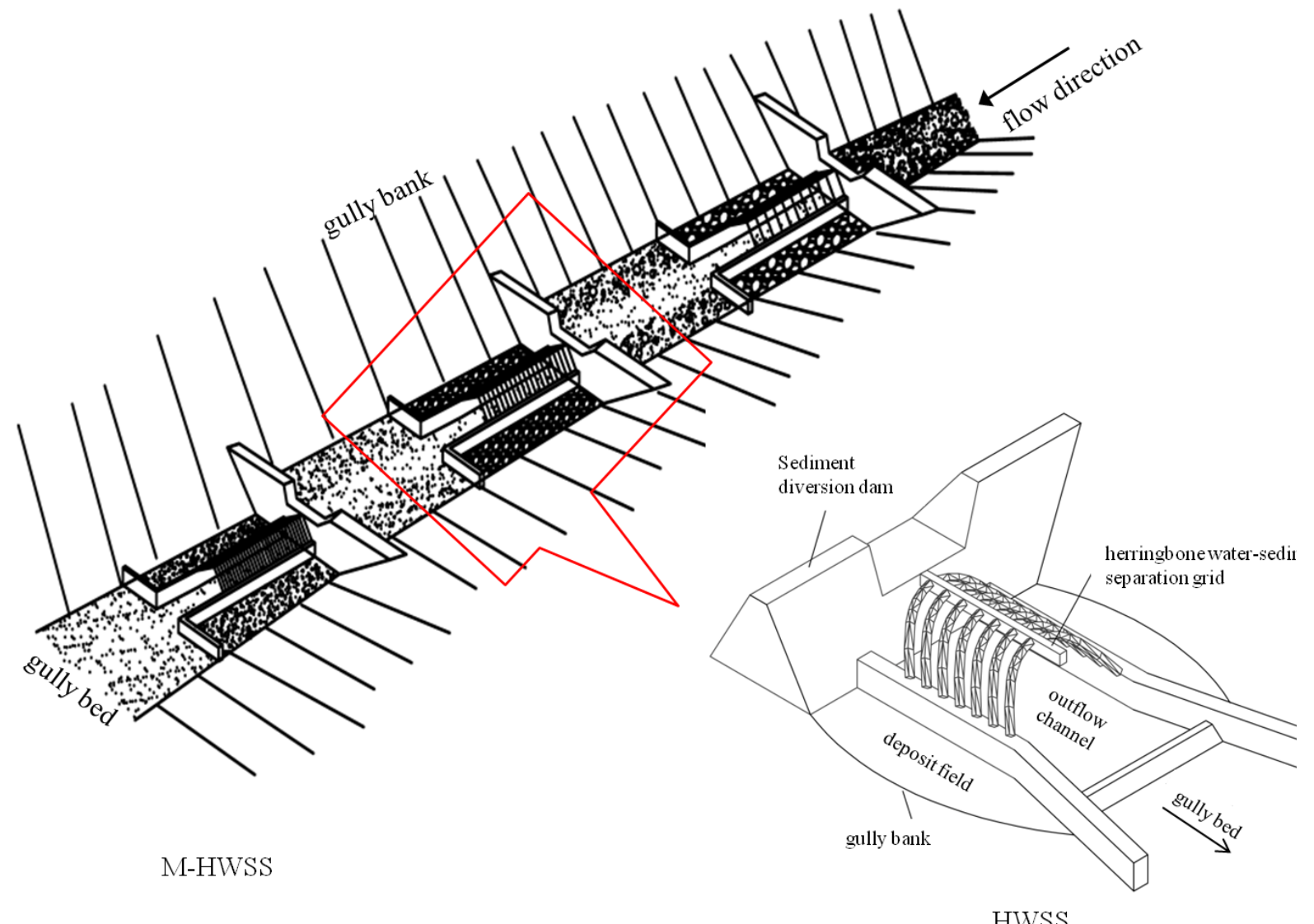

HWSS

Figure 1 A single HWSS and a M-HWSS system

To understand the sediment control effects of a M-HWSS system, it is essential to determine how sequential structures work together. Previous research provides relatively little guidance in this respect. Xie T et al. (2015) and Xie XP et al. (2016), demonstrated through theoretical and experimental research that structure parameters significantly influence sediment separation effects in single structures. While herringbone grid opening widths, for example, are determinants of the

size distribution and volume of separated sediment, there is as yet not a good method for estimating the influence of opening size on sediment control in single or multiple HWSS systems. This paper presents the results of hydraulic model experiments undertaken to demonstrate the synergistic effects between multiple structures with a specific focus on the relationship between sediment control effects and grid opening widths.

\section{Methods and materials}


Nat. Hazards Earth Syst. Sci. Discuss., doi:10.5194/nhess-2016-340, 2016

Manuscript under review for journal Nat. Hazards Earth Syst. Sci.

Published: 25 October 2016

(c) Author(s) 2016. CC-BY 3.0 License.

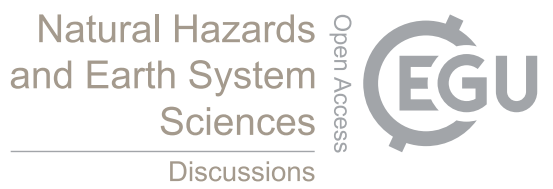

(c) (i)

Grain size is a fundamental property affecting entrainment, transport and deposition of sediment (Blott and Pye2001) with the grain size distribution being a unique descriptor for sediment in a specific debris flow. Therefore, ten 100kg samples were collected from debris flow deposits in the Jiangjia Gully, Yunnan Province, SW China forgrain size distribution analysis and use in the model experiments. The samples were coded B1 through B10 (Table 1).Considering the scale of the

5 model experiments, the maximum grain size diameter used was $60 \mathrm{~mm}$, while $2 \mathrm{~mm}$ was set as the minimum diameter on the

Table 1Grain size distributions for the sediment samples

\begin{tabular}{cccccc}
\hline Grain size & \multicolumn{5}{c}{ Percentage by weight in each grain size class(\%) } \\
\cline { 2 - 6 } samplecode & $60 \sim 40 \mathrm{~mm}$ & $40 \sim 20 \mathrm{~mm}$ & $20 \sim 10 \mathrm{~mm}$ & $10 \sim 5 \mathrm{~mm}$ & $5 \sim 2 \mathrm{~mm}$ \\
\hline B1 & 0 & 32.53 & 27.47 & 19.83 & 20.17 \\
B2 & 0 & 20.61 & 26.68 & 24.57 & 28.13 \\
B3 & 0 & 27.92 & 27.36 & 20.51 & 24.21 \\
B4 & 0 & 10.18 & 25.23 & 29.64 & 34.95 \\
B5 & 0 & 10.16 & 32.34 & 36.06 & 21.47 \\
B6 & 0 & 21.83 & 37.68 & 26.11 & 14.38 \\
B7 & 0 & 3.71 & 36.05 & 34.57 & 25.67 \\
B8 & 0 & 25.20 & 24.76 & 21.43 & 28.61 \\
B9 & 5.17 & 12.70 & 30.72 & 29.15 & 22.26 \\
B10 & 9.51 & 27.77 & 23.07 & 22.77 & 16.88 \\
\hline
\end{tabular}
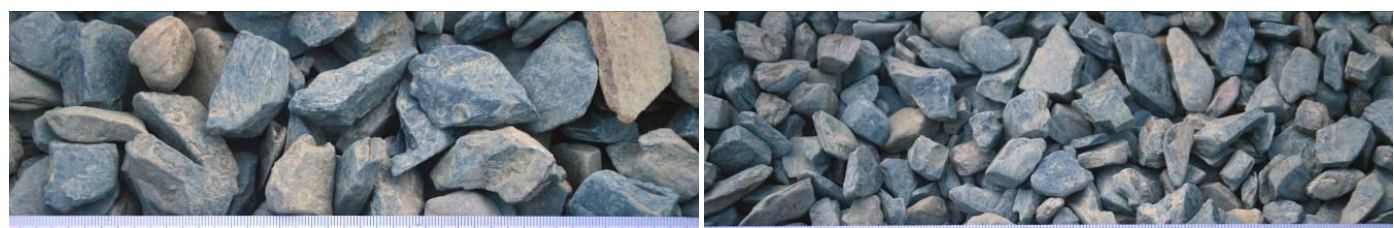

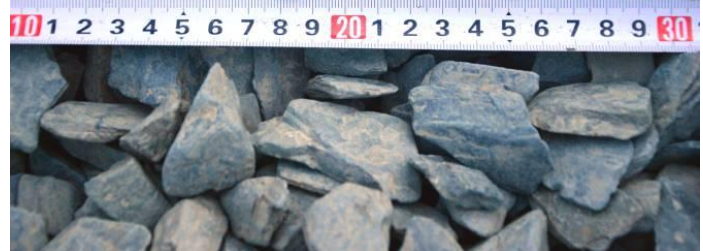

(a) $40 \sim 20 \mathrm{~mm}$

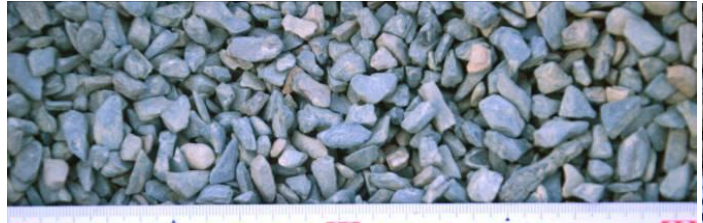

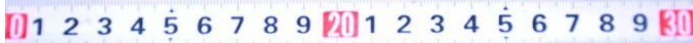

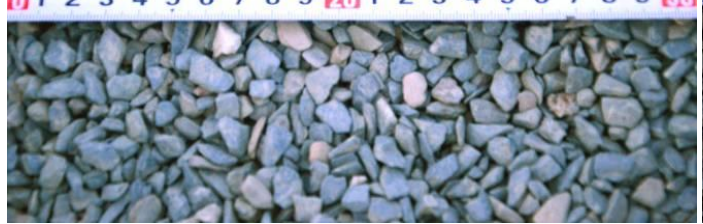

(a) $10 \sim 5 \mathrm{~mm}$

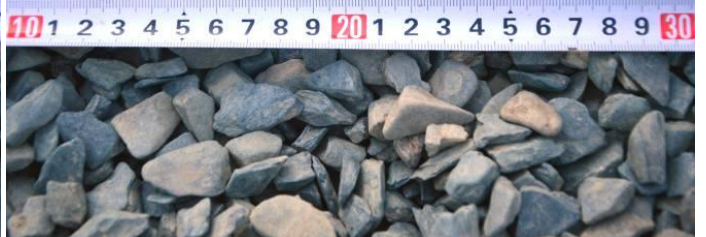

(b) $20 \sim 10 \mathrm{~mm}$

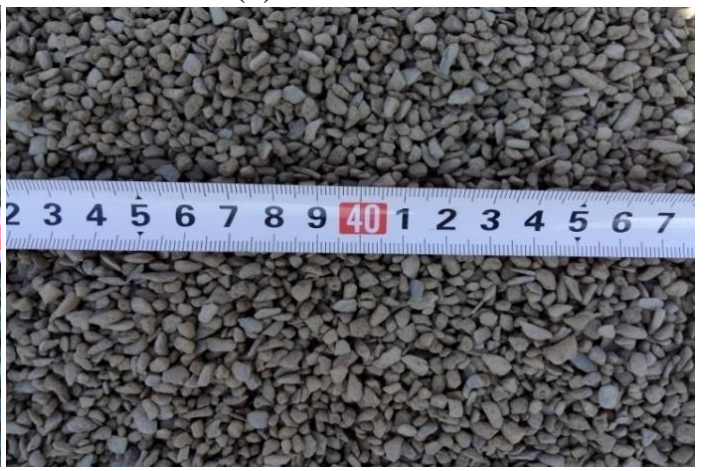

(b) $5 \sim 2 \mathrm{~mm}$

Figure 2 Examples of the sieved sediment samples used in the model experiment. 
Nat. Hazards Earth Syst. Sci. Discuss., doi:10.5194/nhess-2016-340, 2016

Manuscript under review for journal Nat. Hazards Earth Syst. Sci.

Published: 25 October 2016

(C) Author(s) 2016. CC-BY 3.0 License.
Natural Hazards

and Earth System

Sciences

Discussions

(c) $\underset{\mathrm{BY}}{(\mathrm{P})}$

basis of the two-phase flow theory for debris flows where in particles less than 4 6mm behave as part of the liquid component of debris flows (Feiet al.,1991;Shu et al,2008). The HWSS is primarily intended to separate coarse debris that causes impact damage. Within the 2 to $60 \mathrm{~mm}$ range, five grain size classes were set at 60 40mm, 40 20mm, 20 10mm,10 5mm and5 2mm and each of the samples was sieved into the five size classes as shown in Table 1 .

\section{HWSS grid models}

Figure 3 shows the four HWSS grid models used in the experiements. They were identified as GI, GII, GIII and GIV, and designed and constructed to form different combinations in the experimental M-HWSS system. The main parameters of the four models, except for the grid opening width $(D)$, were set the same. The other structural parameters, including width $(B)$, inclined slope of the ribbed beam $(\theta)$, the slope of ribbed beam $(\beta)$ and the length of the structure $(S)$ were set to the

10 optimum values obtained in previous research by Xie T et al.(2015) and Xie XP et al.(2016) .The grid opening width $(D)$ isthe one parameter that was varied in order to influence the sediment control effects and to establish the optimal method for its determination in a M-HWSS system.The initial values for the grid opening width $(D)$ of the four grid models used in

Table 2 the experimental cases.

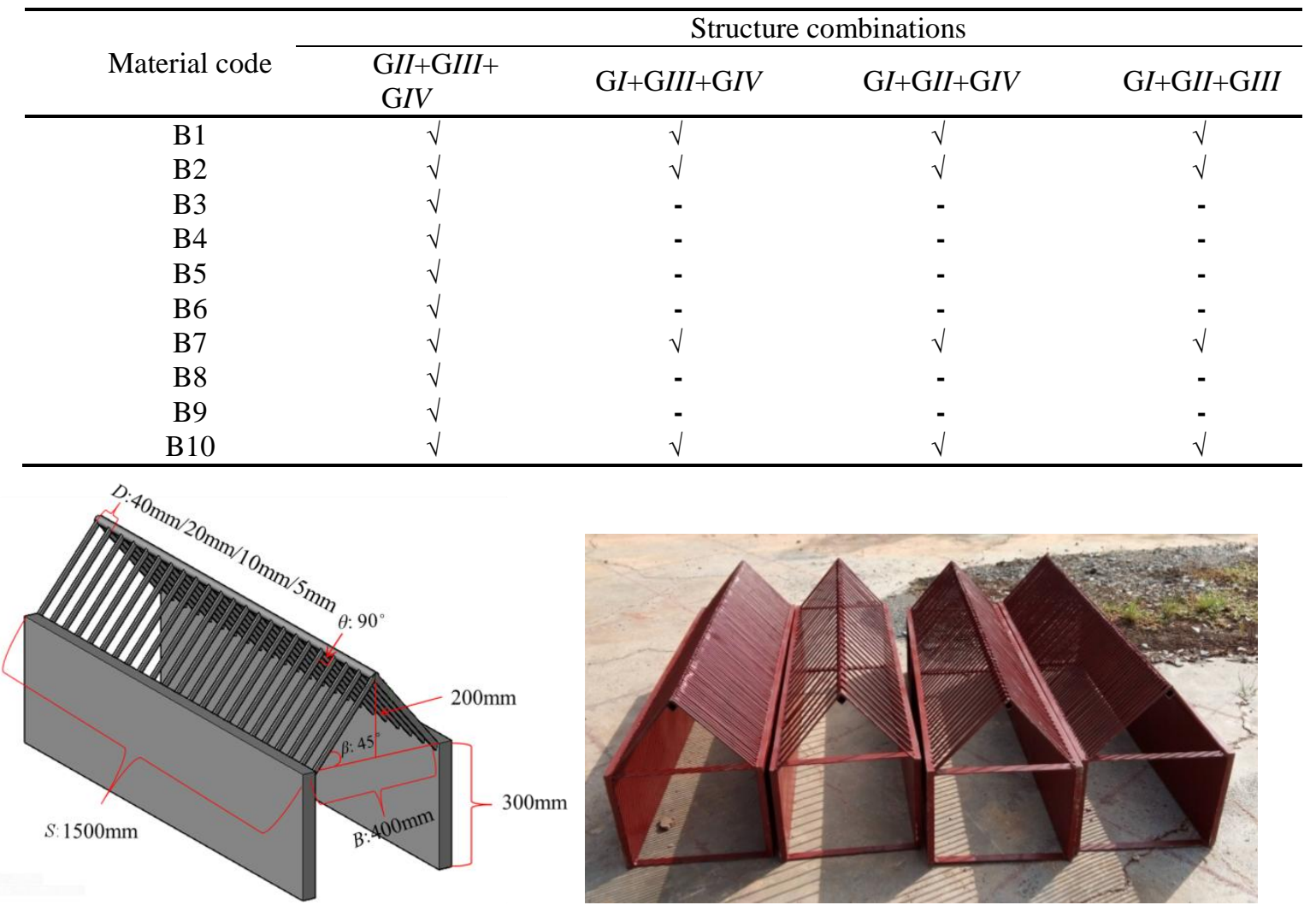

Figure3 Schematic of a HWSS (left)and the four experimental HWSS grid models (right) 
Nat. Hazards Earth Syst. Sci. Discuss., doi:10.5194/nhess-2016-340, 2016

Manuscript under review for journal Nat. Hazards Earth Syst. Sci.

Published: 25 October 2016

(C) Author(s) 2016. CC-BY 3.0 License.
Natural Hazards

and Earth System

Sciences

Discussions

the experiment were $40 \mathrm{~mm}, 20 \mathrm{~mm}, 10 \mathrm{~mm}$ and $5 \mathrm{~mm}$ respectively, based on the boundary diameters of the sample grain size classes.

\section{Experimental conditions}

With the four HWSS grid models, four combinations of a 3-HWSS system were formed as GII+GIII+GIV, $\mathrm{G} I+\mathrm{G} I I+\mathrm{G} I V, \mathrm{G} I+\mathrm{G} I I+\mathrm{G} I V$ and $\mathrm{G} I+\mathrm{G} I I+\mathrm{G} I I I$. Table 2 lists the experimental cases with different sediment size distributions and different structure combinations. Twenty-two group tests were conducted at the Dongchuan Debris Flow Observation and Research Station, in Yunnan Province where the 4 structural combinations were arranged in a flume (Fig. 4). The experimental flume device consisted of four sections with the same bed slope of $200 \%$. Flume $I$ was $6 \mathrm{~m}$ long, $40 \mathrm{~cm}$ wide, $50 \mathrm{~cm}$ deep. From the downstream end at $1.0 \mathrm{~m}$, the width was narrowed gradually to $20 \mathrm{~cm}$.Flumes $I I$ and $I I I$ were $5 \mathrm{~m}$ long,

$1040 \mathrm{~cm}$ wide and $50 \mathrm{~cm}$ deep and the upstream ends at $1.1 \mathrm{~m}$ were narrowed gradually to $20 \mathrm{~cm}$. Flume $I V$ formed a drainage channel. Herringbone structures with deposit cases, acting as deposit fields, were set downstream from Flumes I,II and III. Each deposit case was $1.5 \mathrm{~m}$ long, $1.0 \mathrm{~m}$ wide and $1.0 \mathrm{~m}$ deep.The experimental sediment samples were placed in the $2 \sim 4 \mathrm{~m}$ section of Flume I to a depth of about $10 \mathrm{cms}$.Each of the samples contained a mixture of each of the experimental sediment size groups. A constant water discharge of $4.51 \mathrm{~L} / \mathrm{s}$ from the water pond was used to wash all the sediment from Flume $I$ to

15 the first HWSS and the following flumes and HWSSs. When all the sediment was flushed out of Flumes $I, I I$ and $I I I$, that

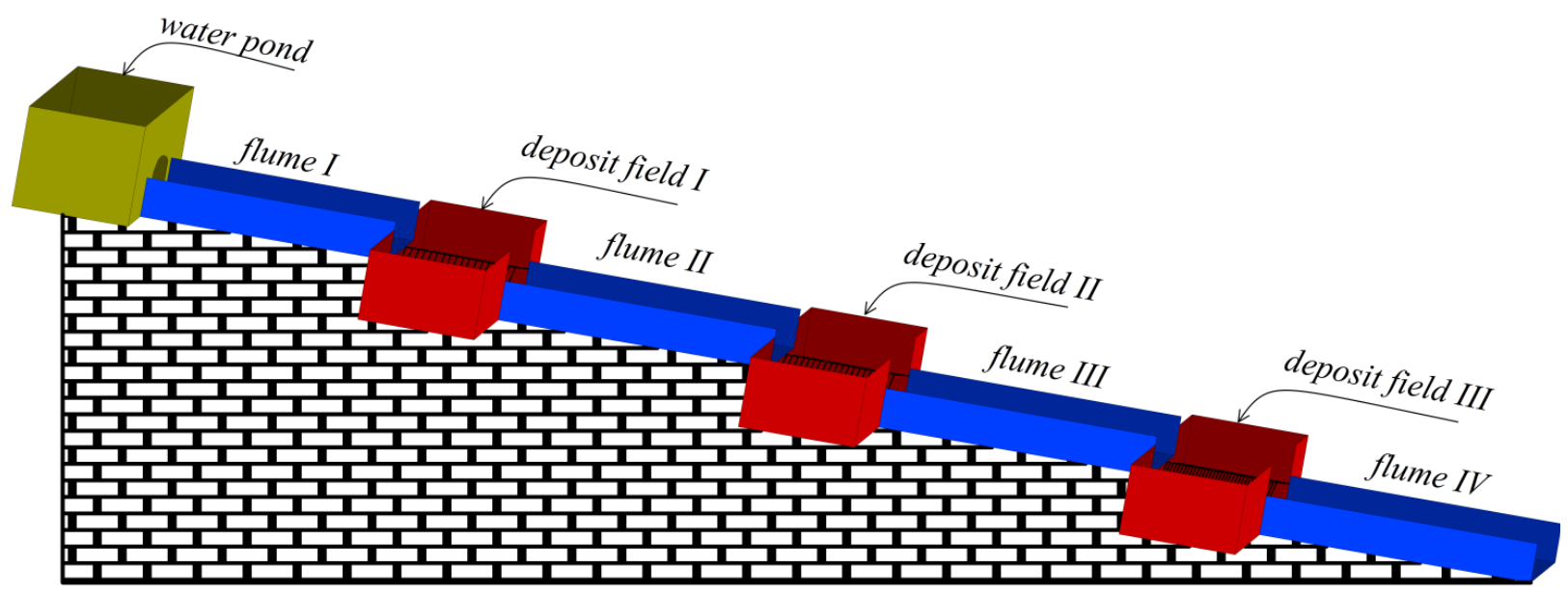

three dimensional view

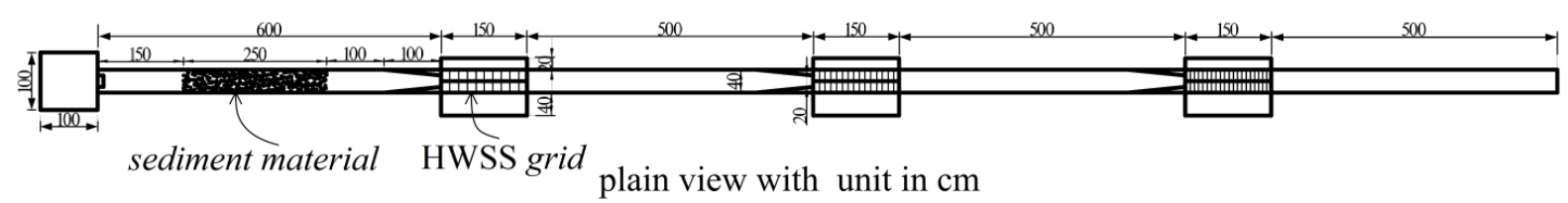

Figure 4 The experimentalflume with M-HWSSs and deposit fields (cases). 
Nat. Hazards Earth Syst. Sci. Discuss., doi:10.5194/nhess-2016-340, 2016

Manuscript under review for journal Nat. Hazards Earth Syst. Sci.

Published: 25 October 2016

(c) Author(s) 2016. CC-BY 3.0 License.

(c) (i)
Natural Hazards

and Earth System

Sciences

Discussions

which was separated into the deposit cases was collected, dried, sieved and weighed.

\section{Measured parameters}

Previous research indicated that the HWSS reduced the total quantity of discharged sediment and shifted the grain size distribution toward a smaller fraction. The parameters directly measuredwere the mass of each grain size class in the input sediment sample and that of each grain size class in the separated sediment samples.Indirect indexes that describe the characteristics of grain size distributions and the sediment control effects were then calculated on the basis of the directly measured parameters.

\section{Parameters for grain size distribution analysis}

Grain size distribution reflects the hydraulics of flow and the sediment transport rate (Bunte, 2001). Measures to describe characteristics of sediment samples, such as mean grain size, sorting, etc.,have been developed and in use for some time (Folk and Ward,1954; Friedman and Johnson,1982; McManus, 1988). In this research, the logarithmicmoment method ofBlott and Pye(2001) to calculate the mean grain size diameter $\left(M_{\psi}\right)$ (Formula 1) and standard deviation $\left(\sigma_{\psi}\right)$ (Formula 2$)$ is used. Cumulative frequency curves were also used for comparison of the original input material and discharged material by different HWSS structures.

15

$$
M_{\psi}=\frac{\sum f \cdot d_{m_{\psi}}}{100}
$$

$$
\sigma_{\psi}=\sqrt{\frac{\sum f \cdot\left(d_{m \psi}-M_{\psi}\right)^{2}}{100}}
$$

Where, $f$ is the frequencyof each size class in percent $(\%) ; d_{m \psi}$ is the mid-point of each class interval in $\psi$ - unit. $\psi$ - unit is the negative value obtained in $\varphi$-unit that was developed to produce positive values for large particle sediment situation (Bunte, 2001).

\section{Parameters for sediment control effect evaluation}

Two parameters were developed to measure the change of total sediment and coarse debris fraction in order to evaluate the efficiency of sediment control. They are the total sediment separation $\operatorname{rate}\left(P_{\mathrm{t}}\right)$ and fraction separationratio $\left(\lambda_{i}\right)$ respectively. $P_{\mathrm{t}}$ is the proportion of the mass of separated sediment against the mass of input sediment. $\lambda_{i}$ is the ratio between the mass of each grain size class in the separated sediment and that in the corresponding input sediment .In evaluating a M-HWSS system, both the total sediment control effect of the system and that in each HWSS must be considered, in particular to assess the interaction among structures. Figure 5 illustrates the difference and relationship of these two aspects. 
Nat. Hazards Earth Syst. Sci. Discuss., doi:10.5194/nhess-2016-340, 2016

Manuscript under review for journal Nat. Hazards Earth Syst. Sci.

Published: 25 October 2016

(c) Author(s) 2016. CC-BY 3.0 License.

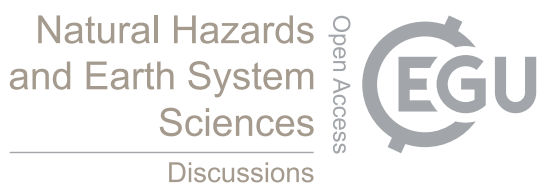

(c) (1)

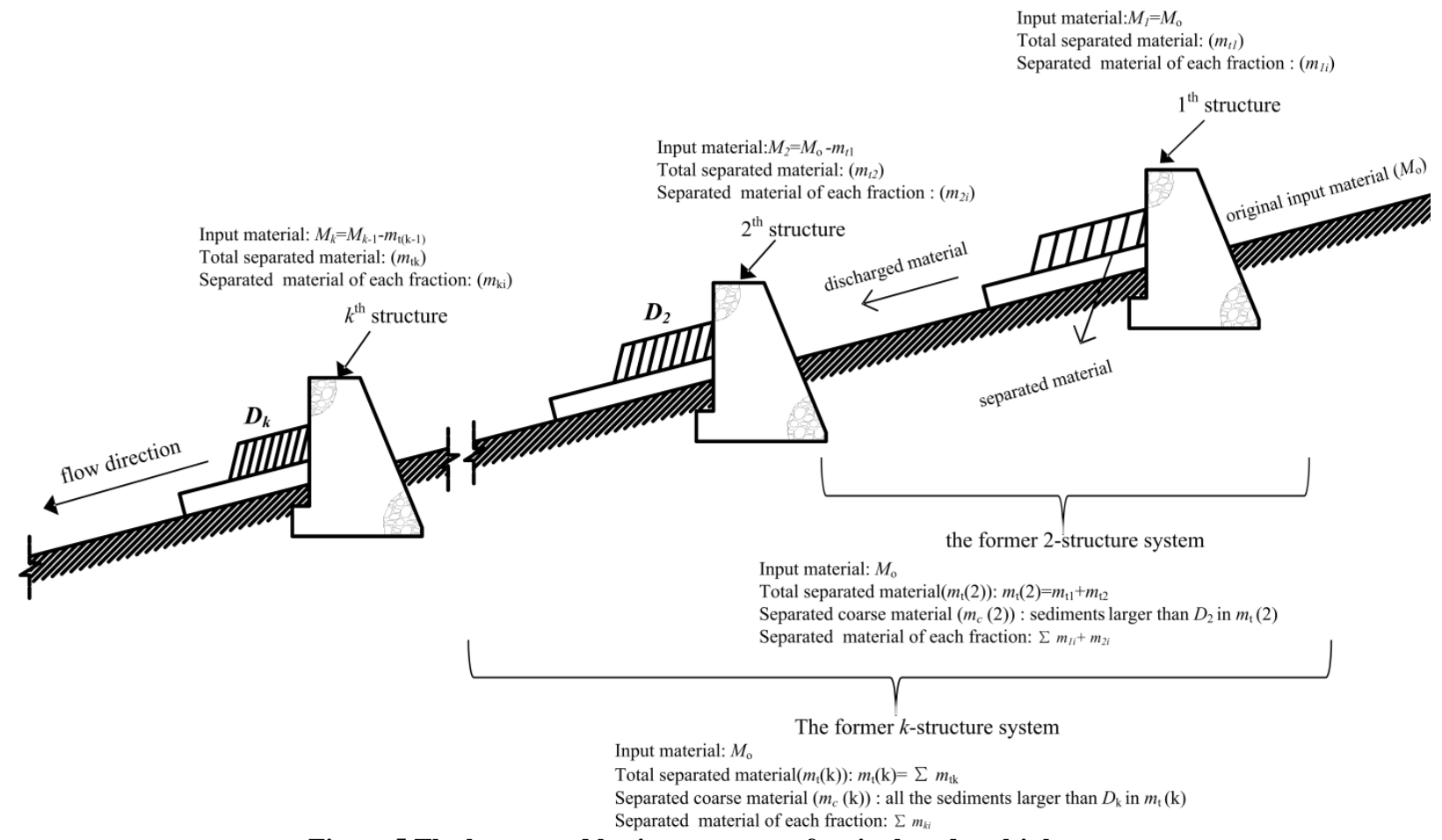

Figure 5 The layout and basic parameters for singleand multiple structures

For the $k^{\text {th }}$ structure in a $n$-HWSS system, thesubscript $k$ is used to denote its structural parameters (eg. $\left.D_{\mathrm{k}}\right)$ and control effect parameters $\left(\mathrm{eg}: P_{t k}, \lambda_{i k}\right)$. For the k-former structures, $k$ with parenthesis $(\mathrm{k})$ is used to express the synergetic control effect (eg: $\left.P_{t}(\mathrm{k}), \lambda_{i}(\mathrm{k})\right)$. The definitions of $P_{\mathrm{t}}$ and $\lambda_{i}$ may be expressed as following equations:

For a single structure:

$$
\begin{aligned}
& P_{t k}=\frac{m_{t k}}{M_{k}} \times 100 \% \\
& \lambda_{i k}=\frac{m_{t k i}}{M_{k i}}
\end{aligned}
$$

In which, $m_{\mathrm{tk}}$ is the total separated sediment mass of $k^{\text {th }}$ structure, $m_{k i}$ the mass of each grain fractioninseparated sediments. $M_{\mathrm{k}}$ is the input material for the $k^{\text {th }}$ structure, which equals the discharged material of $(k-1)^{\text {th }}$ structure, assuming no replenishment of material along the way, i.e. $M_{\mathrm{k}}=M_{\mathrm{k}-1}-m_{\mathrm{tk}}$ and $M_{\mathrm{k} i}$ is the mass of each grain size fraction inthe $k^{\text {th }}$ input material

For $k$-former structures:

$$
P_{t}(k)=\frac{m_{t}(k)}{M_{o}} \times 100 \%=\frac{\sum_{j=1}^{k} m_{t j}}{M_{o}} \times 100 \%
$$


Nat. Hazards Earth Syst. Sci. Discuss., doi:10.5194/nhess-2016-340, 2016

Manuscript under review for journal Nat. Hazards Earth Syst. Sci.

Published: 25 October 2016

(c) Author(s) 2016. CC-BY 3.0 License.

$\lambda_{i}(k)=\frac{m_{i}(k)}{M_{o i}}=\frac{\sum_{j=1}^{k} m_{t j i}}{M_{o i}}$

Where, $m_{\mathrm{t}}(\mathrm{k})$ is the total separated sediment mass ofthekstructures,For multiple structures analysis, the input material is always the original input material $\left(M_{\mathrm{o}}\right)$ and $M_{\mathrm{oi}}$ is the mass of each grain fraction in original total sediment.

\section{Results and analysis}

\section{Separated sediment sorting}

An initialvisual impression showsupstream to downstream and coarser to finer sorting of sediment, which is confirmed by the mean diameter $\left(M_{\psi}\right)$ of sequential structures from upstream to downstream (Fig.6).

The standard deviations $\left(\sigma_{\psi}\right)$ also demonstrate improved sorting from upstream to downstream of separated sediment and as compared with the original input sediment. According to Blott and Pye(2001), sorting as expressed by $\sigma_{\psi}$ may be classified into seven levels as follows: very well sorted $\left(\sigma_{\psi}<0.35\right)$, well sorted $(0.35 \sim 0.5)$, moderately well sorted (0.5 7.0), moderately sorted (0.7 1.0) and poorly sorted (1.0 2.0),very poorly sorted (2.0 4.0) and extremely poorly sorted (>4). Most of the sediments separated by sequential structures were moderately sorted while the input materials were poorly sorted (Fig 7). The sorting may be improved by further optimization of the HWSS structure parameters such that the separated sediment would qualify as construction material, thus adding a further benefit of the system.

For the case of sample B7, the first structure GII exerts a better sorting effect than GI because the grid opening width of the latter is much larger than the mean diameter of input material and therefore itcannot perform a sortingfunction in this case. This phenomenon is discussed further in the following.

\section{Discharged sediments and their grain size distributions}

Mean diameter $\left(M_{\psi}\right)$ summarizes the grain size of a sediment sample and itstransportability.In Fig.8, the $M_{\psi}$ of the sequentially discharged sediment is seen to drop dramatically in the first two structures as compared to the input samples. For the GII+GIII+GIV combination, significant decreases in mean grain size in discharged sediment occurat the first and second separation structures. For other combinations, distinct reductions in $M_{\psi}$ occurred at the second separation structure.. This result reflects different sorting effects by different structures and structure combinations.

Grain size cumulative frequency distribution curves help to understand and explain the different sorting effects for different structures (Fig.9).Taking B1 as an example, under the GII+GIII combination (Fig.9 (a)), the grain size distribution changed after each structure, especially the portion of fractions larger than the grid opening width. The portion of sediment larger than $20 \mathrm{~mm}$ was less than $3 \%$ in the GII-discharged material and $14.64 \%$ for sediment larger than $10 \mathrm{~mm}$ in GIIIdischarged material.The corresponding values for the B1 input material were $32.53 \%$ and $60 \%$ respectively. The same situation applied to B2 with GII+GIII (Fig.9(b)). This suggests that GII and GIII have strong sortingfunctions.However, with 
Nat. Hazards Earth Syst. Sci. Discuss., doi:10.5194/nhess-2016-340, 2016

Manuscript under review for journal Nat. Hazards Earth Syst. Sci.

Published: 25 October 2016

(C) Author(s) 2016. CC-BY 3.0 License.
Natural Hazards o

and Earth System

Sciences

Discussions

\section{(c) $\underset{\mathrm{BY}}{(\mathrm{P})}$}

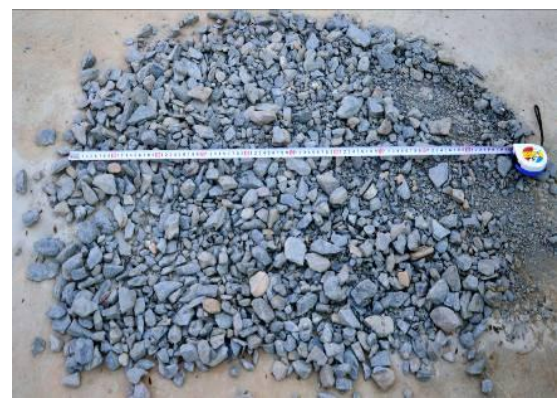

GII-separated sediment

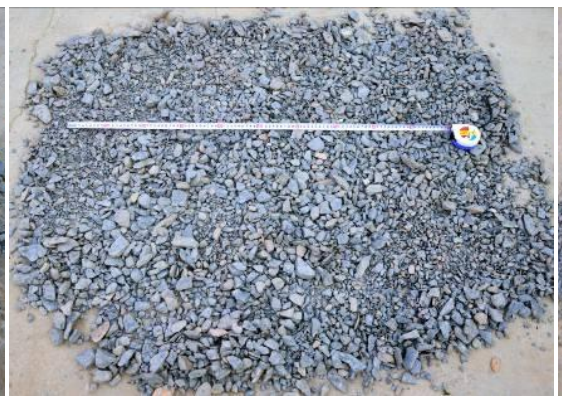

GIII-separated sediment

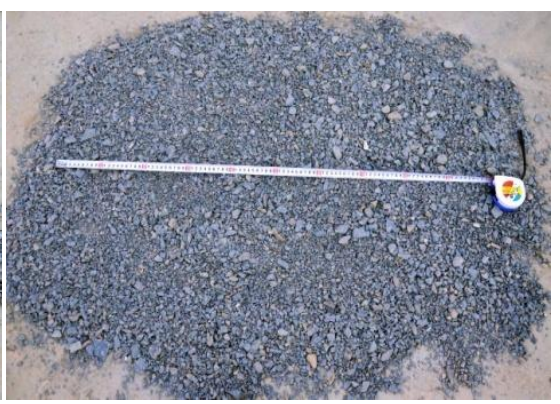

GIV-separated sediment

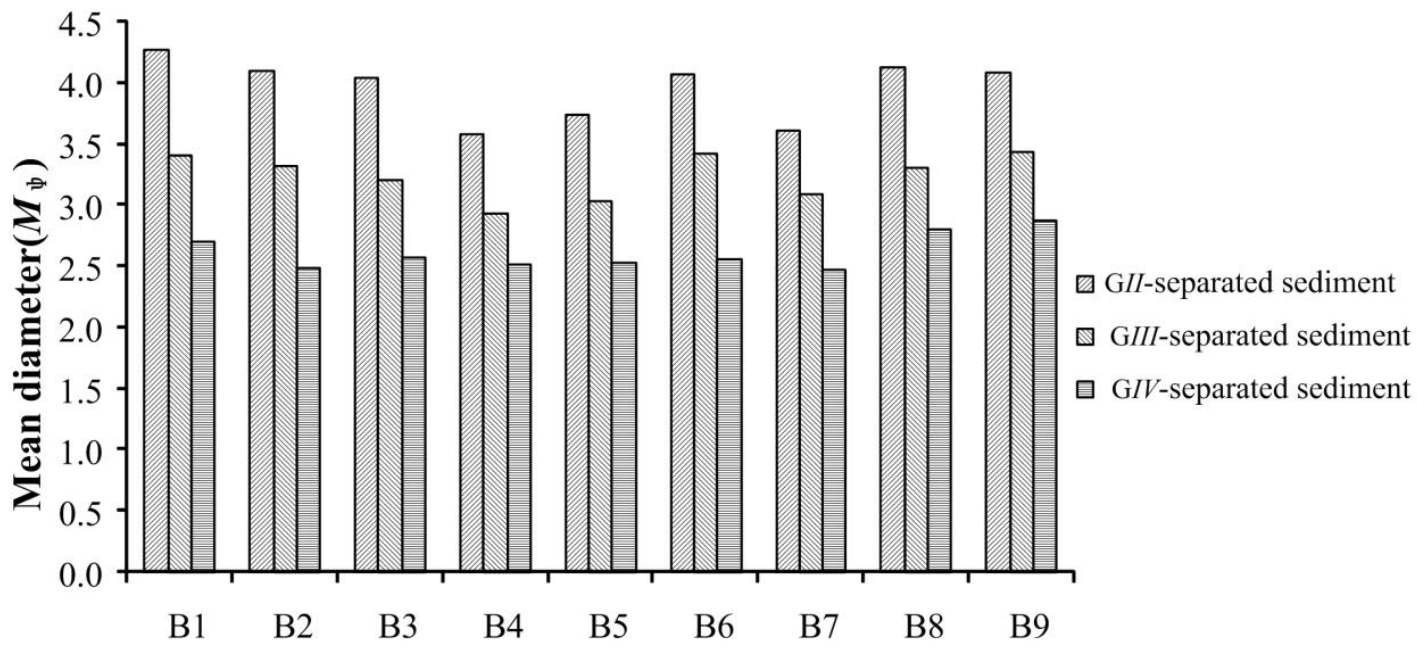

Figure 6 Separated sediments from upstream to downstream under the combination of GII+GIII+GIV. up: a picture of one of the separated sediment by GII+GIII+GIV; below: the mean diameters of each case under GII+GIII+GIV

similar input material, sorted grain size distributions vary under different M-HWSS systems. For example, sample B1 when discharged at GI, has much the same grain size distribution as that for the input material as illustrated in Fig. 9(c) and in contrast to that for B1-GII (Fig. 9(a)). This may be explained bythe fraction separation ratio (see 4.3.1). When the relative opening width $\left(D_{\mathrm{k}} / d_{\mathrm{mi}}\right)$ is larger than 1 , the difference in fraction separation ratios are minor. When $D_{\mathrm{k}} / d_{\mathrm{m}}<1$, the sorting

5 function increased significantly for the coarse fractions causing differences in the grain size cumulative frequency curves between the input and sorted material. This is illustrated by the examples of B2-GI+GIII and B7-GI+GIII (Fig.9 (d)(e)) while the opposite is seen in B10-GI+GIII (Fig.9(f)).

Unexpectedly, the $M_{\psi}$ of the $3^{\text {rd }}$ discharged sediment as compared with the $2^{\text {nd }}$ discharged sediment is constant or increased in most cases. The reason may lie in the moment method where outliers in the frequency distribution strongly

10 influence the $M_{\psi}$ (McManus, 1988). This was the case for the grain size distribution in the $3^{\text {rd }}$ discharged sample. Notwithstanding the variability in the results, the general tendency for the mean diameter to decrease downstream indicates that, through sequential separation of coarse sediment and debris, a debris flow can be expected to transform into sedimentladen flow. An optimal number of structures remains a question and may vary under differing specific conditions. 
Nat. Hazards Earth Syst. Sci. Discuss., doi:10.5194/nhess-2016-340, 2016

Manuscript under review for journal Nat. Hazards Earth Syst. Sci.

Published: 25 October 2016

(c) Author(s) 2016. CC-BY 3.0 License.
Natural Hazards 음

and Earth System

Sciences

Discussions

\section{(c) $\underset{\mathrm{BY}}{(i)}$}
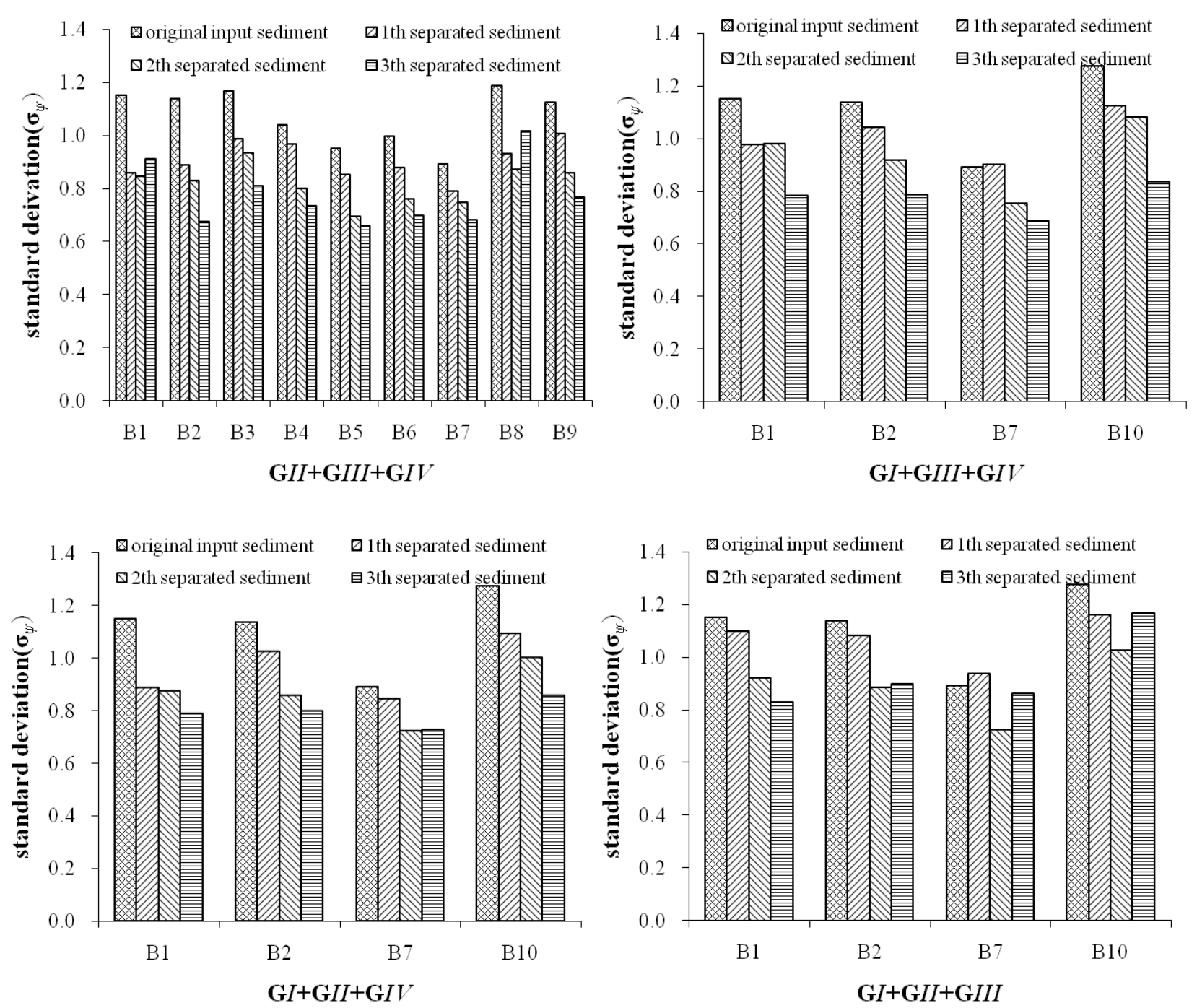

Figure 7 Sediment deviations for the separated material

\section{Influence of opening width on the sediment control effect}

Earlier it was mentioned that the sediment control effect is influenced primarily by the composition of the input sediment and the HWSS characteristics, particularly the grid opening width $(D)$.Quantitative relationships between these factors are expected to guide the structure design. Two parameters, the fraction separation ratio and total separation rate are

5 assessed under single and multiple structure conditions. 
Nat. Hazards Earth Syst. Sci. Discuss., doi:10.5194/nhess-2016-340, 2016

Manuscript under review for journal Nat. Hazards Earth Syst. Sci.

Published: 25 October 2016

(c) Author(s) 2016. CC-BY 3.0 License.
Natural Hazards 웅 and Earth System

Sciences

Discussions

\section{(c) $\underset{\mathrm{BY}}{(i)}$}
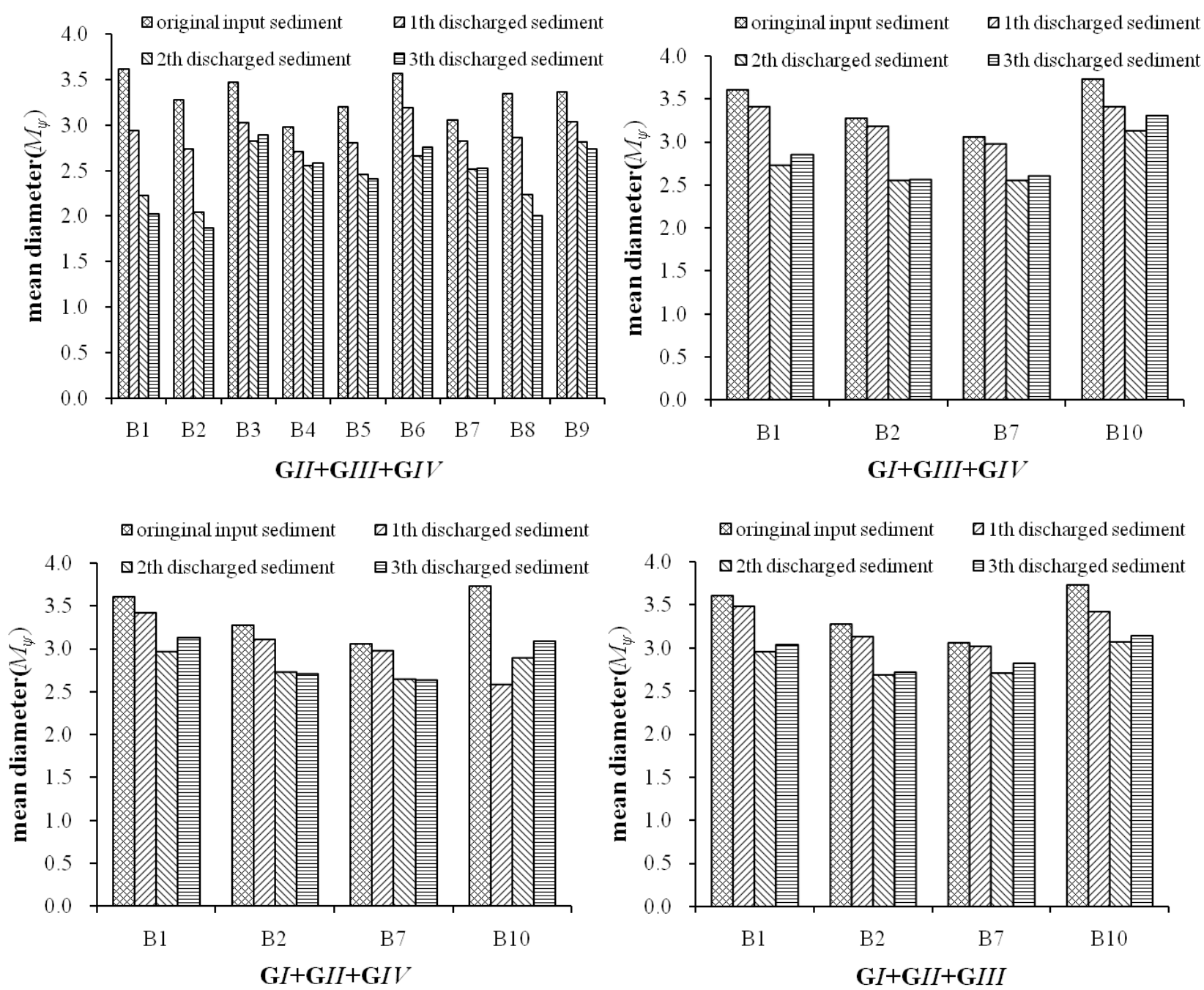

Figure 8 Mean diameter of discharged sediment

\section{Single structure conditions}

(1) Fraction separation ratio $\left(\lambda_{\mathrm{i} k}\right)$

The fraction separation ratio permits the evaluation of sieving effects on different grain size fractions. Thecalculated fraction separation ratio under the $k^{\text {th }}$ structure $\left(\lambda_{i k}\right)$ for all the experimental conditions, produces a power relationship 5 between $\lambda_{i k}$ and $D_{\mathrm{k}} / d_{m \mathrm{i}}$ with $\mathrm{R}^{2}=0.8575$ (Fig. 10), after removal of some abnormal values:

$$
\lambda_{\mathrm{ik}}=0.552\left(\frac{D_{k}}{d_{m i}}\right)^{-0.787}
$$


Nat. Hazards Earth Syst. Sci. Discuss., doi:10.5194/nhess-2016-340, 2016

Manuscript under review for journal Nat. Hazards Earth Syst. Sci.

Published: 25 October 2016

(c) Author(s) 2016. CC-BY 3.0 License.
Natural Hazards

and Earth System

Sciences

Discussions

(c) $\underset{\mathrm{By}}{(-)}$

Where, $D_{\mathrm{k}}$ is the $k^{\text {th }}$ grid opening width and $\mathrm{d}_{m i}$ is the mid-diameter of each grain size class, that is, the arithmetic mean of each grain size class. $D_{\mathrm{k}} / d_{m \mathrm{i}}$ then can be defined as the fraction-scale relative opening width. This relationship explains the phenomena mentioned in section 4.2. The minimum fraction-scale relative opening width of GI is larger than 1.33, so that $\lambda_{i k}$ is slow, which means the difference of sieving effect for every fraction is not so obvious and reflects on the similarity of the
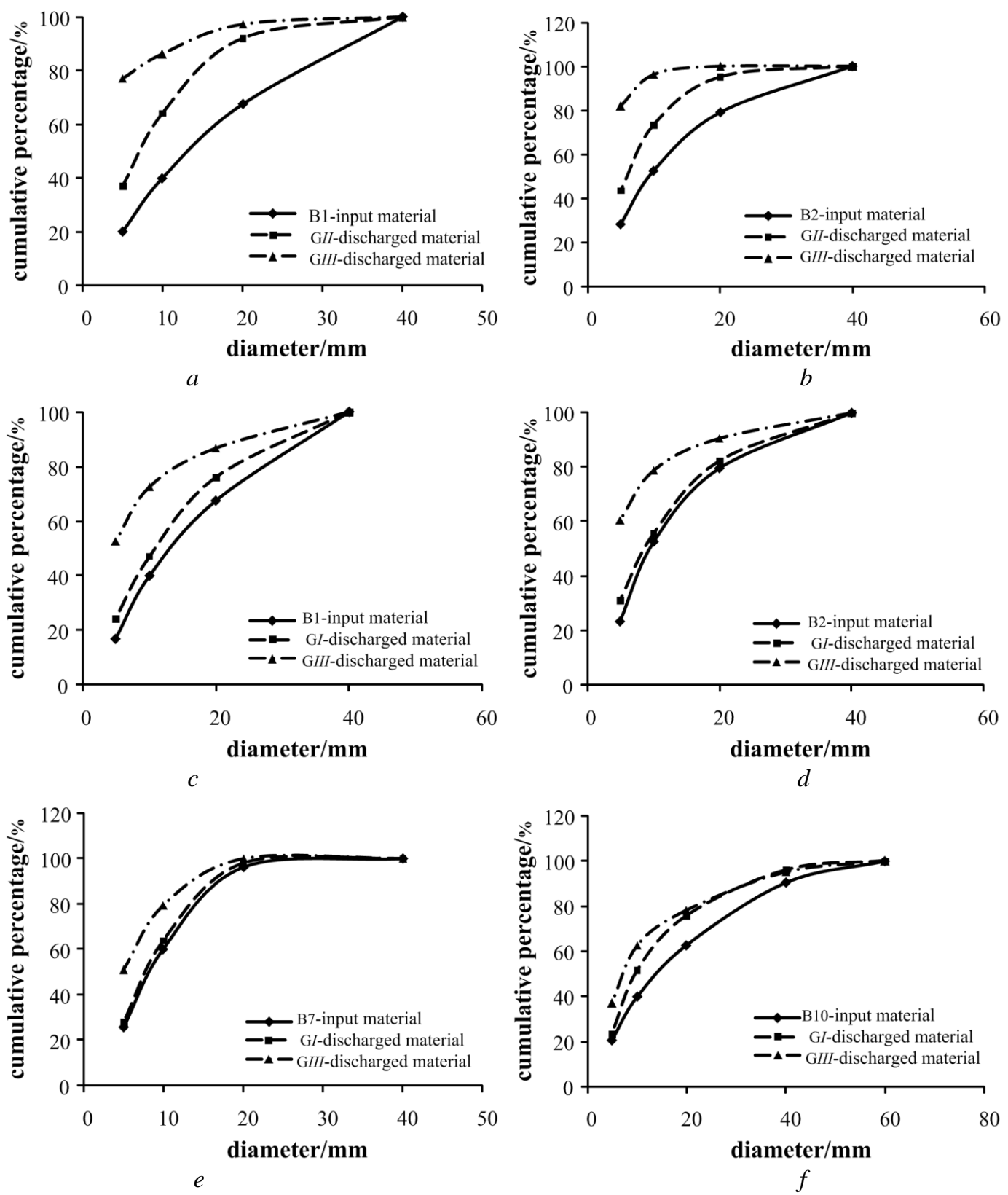

Figure 9 Grain size cumulative frequency curves for input material and discharged material 
Nat. Hazards Earth Syst. Sci. Discuss., doi:10.5194/nhess-2016-340, 2016

Manuscript under review for journal Nat. Hazards Earth Syst. Sci.

Published: 25 October 2016

(C) Author(s) 2016. CC-BY 3.0 License.

(c) (i)
Natural Hazards

and Earth System

Sciences

Discussions

cumulative frequency curves. For the grids of GII and GIII, $D_{\mathrm{k}} / d_{m i}$ of the coarse fractions (grain diameter larger than $D_{\mathrm{k}}$, that is, 40 20 10mm) are less than 1, meaning that $\lambda_{i k}$ of these coarse fractions are at least larger than 0.55 , which causes distinct changes on the cumulative frequency curves due to significant sieve effects.

(2) Partial separation ratio

All fractions can be separated into two parts, the coarse part (fractions larger than $D_{\mathrm{k}}$ ) and fine part (fractions smaller than $\left.D_{\mathrm{k}}\right)$. The integrated index of coarse separation ratio $\left(\lambda_{c k}\right)$ and fine separation ratio $\left(\lambda_{f k}\right)$ can be used to depict the average separation ratio of coarse fractions and fine fractions and may be expressed as:

$$
\begin{aligned}
& \lambda_{c k}=\frac{m_{k c}}{M_{k c}}=\frac{\sum_{d i>D_{k}} m_{k i} / M_{k}}{\sum_{d i>D_{k}} M_{k i} / M_{k}}=\frac{P_{c k}}{f_{c k}} \\
& \lambda_{f k}=\frac{m_{f c}}{M_{f c}}=\frac{\sum_{d i<D_{k}} m_{k i} / M_{k}}{\sum_{d i<D_{k}} M_{k i} / M_{k}}=\frac{P_{f k}}{f_{f k}}=\frac{P_{t k}-P_{c k}}{100-f_{c k}}
\end{aligned}
$$

10 Where, $m_{\mathrm{kc}}$ is the mass of the total separated coarse debris by $k^{\text {th }}$ structure and $M_{\mathrm{kc}}$ is the mass of the coarse fraction of the $\mathrm{k}^{\text {th }}$ input material. $P_{\mathrm{ck}}$ is defined as the coarse separation rate and $f_{\mathrm{ck}}$ is the cumulative frequency of coarse fraction in the $k^{\text {th }}$ input material in percent.

Regression analysis illustrates a strong linear relationship between $P_{c k}$ and $f_{c k}$ (Fig.11). With $\mathrm{R}^{2}=0.952, \lambda_{c k}$ could be treated as a constant of 0.771 . However, $\lambda_{f k}$ does not share such a strong relationship with $\left(P_{\mathrm{tk}}-P_{\mathrm{ck}}\right)$ and $f_{\mathrm{ck}}$. we try other

15 attempts to find a relationship expressed by some assigned parameters as grid opening $\operatorname{width}\left(D_{\mathrm{k}}\right)$, grain $\operatorname{size} \operatorname{diameters}\left(d_{\mathrm{i}}\right)$ as inspired by equ.7. Considering that $\lambda_{f k}$ is a partial separation ratio parameter, we define a corresponding fine fraction diameter $d_{\mathrm{fk}}$ to express $\lambda_{f k}$ as follows:

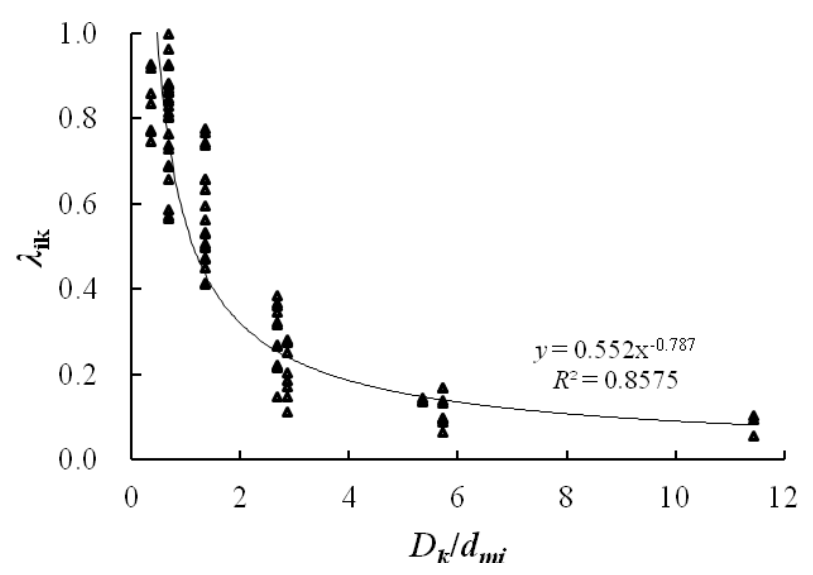

Figure10 Relationship between $\lambda_{i k}$ and $D_{\mathrm{k}} / d_{m \mathrm{i}}$

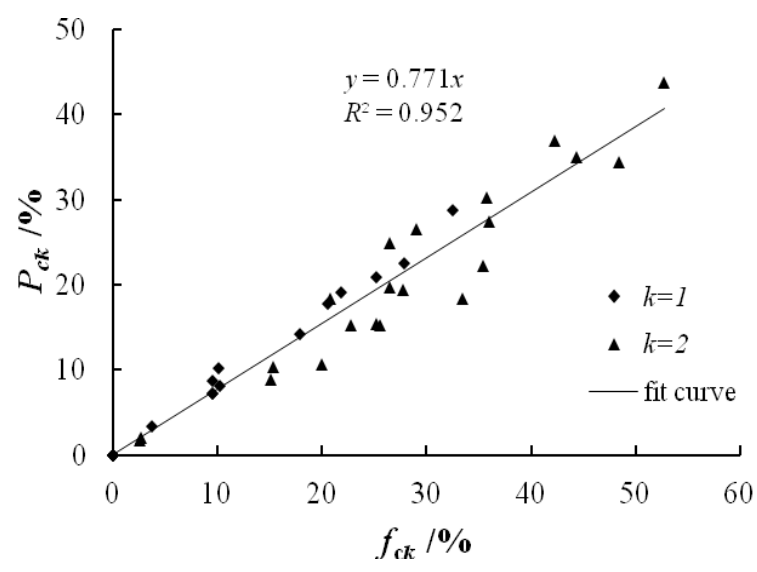

Figure11 1Regression result of $\lambda_{c k}$ by $P_{c k}$ and $f_{c k}$ 
Nat. Hazards Earth Syst. Sci. Discuss., doi:10.5194/nhess-2016-340, 2016

Manuscript under review for journal Nat. Hazards Earth Syst. Sci.

Published: 25 October 2016

(C) Author(s) 2016. CC-BY 3.0 License.
Natural Hazards and Earth System Sciences

$$
\lambda_{f k}=a\left(\frac{D_{k}}{d_{f k}}\right)^{b}
$$

Where, $a$ and $b$ are coefficients that need to be determined. $d_{\mathrm{fk}}$ is the arithmetical mean diameter of fine fraction which can be expressed as Eq.10:

$$
d_{f k}=\frac{\sum d_{m_{j}} \cdot w_{j k}}{\sum w_{j k}}
$$

5 Where, $\mathrm{d}_{m \mathrm{j}}$ is the mid-diameter of fine grain size classes, for the fractions without lower limit or upper limit, $\mathrm{d}_{m \mathrm{j}}$ equals to the other limit value, eg: for the fraction of $d<1 \mathrm{~mm}, d_{m}=1 \mathrm{~mm} \cdot w_{\mathrm{j}}$ is the frequency of fine fraction for the $k^{\text {th }}$ separated sediment, as a percentage or fraction. Table 3 lists the calculated $d_{\mathrm{fk}}$ based on the experimental results.

Regression analysis demonstrated that the coefficients of $a$ and $b$ are equal to 1.177 and -1.603 respectively with

\begin{tabular}{|c|c|c|c|c|c|c|c|c|c|}
\hline $\begin{array}{l}\text { Structure } \\
\text { combination }\end{array}$ & $\begin{array}{l}\text { Material } \\
\text { code }\end{array}$ & $\begin{array}{l}P_{\mathrm{c} 1} \\
(\%)\end{array}$ & $\begin{array}{l}v P_{\mathrm{c} 2} \\
(\%)\end{array}$ & $\begin{array}{l}f_{c 1} \\
(\%)\end{array}$ & $\begin{array}{l}f_{c 2} \\
(\%)\end{array}$ & $\begin{array}{l}P_{\mathrm{t1}} \\
(\%)\end{array}$ & $\begin{array}{l}P_{\mathrm{t} 2} \\
(\%)\end{array}$ & $\begin{array}{l}D_{f 1} \\
(\mathrm{~mm})\end{array}$ & $\begin{array}{l}D_{f 2} \\
(\mathrm{~mm})\end{array}$ \\
\hline \multirow{9}{*}{$\mathrm{G} I I+\mathrm{G} I I I+\mathrm{G} I V$} & B1 & 28.70 & 30.29 & 32.53 & 35.80 & 50.77 & 62.39 & 9.56 & 5.63 \\
\hline & B2 & 17.81 & 24.94 & 20.61 & 26.48 & 39.94 & 54.61 & 8.84 & 5.55 \\
\hline & B3 & 22.57 & 22.24 & 27.92 & 35.44 & 48.73 & 52.53 & 9.23 & 5.57 \\
\hline & B4 & 8.20 & 10.73 & 10.18 & 19.93 & 38.88 & 40.45 & 8.31 & 5.53 \\
\hline & B5 & 10.15 & 18.37 & 10.16 & 20.82 & 46.81 & 60.91 & 9.41 & 6.08 \\
\hline & B6 & 19.05 & 36.87 & 21.83 & 42.20 & 46.26 & 68.92 & 10.50 & 6.28 \\
\hline & B7 & 3.37 & 18.82 & 3.71 & 27.69 & 30.14 & 52.53 & 9.28 & 5.88 \\
\hline & B8 & 20.92 & 26.55 & 25.20 & 29.00 & 42.67 & 59.36 & 8.71 & 5.41 \\
\hline & B9 & 14.26 & 18.35 & 17.87 & 33.49 & 35.59 & 36.38 & 9.41 & 5.97 \\
\hline \multirow{4}{*}{$\mathrm{G} I+\mathrm{G} I I I+\mathrm{G} I V$} & B1 & 0.00 & 43.71 & 0.00 & 52.74 & 25.58 & 66.80 & 16.07 & 5.44 \\
\hline & B2 & 0.00 & 35.05 & 0.00 & 44.32 & 14.59 & 56.06 & 13.20 & 5.67 \\
\hline & B7 & 0.00 & 27.38 & 0.00 & 36.04 & 16.94 & 57.71 & 10.01 & 5.75 \\
\hline & B10 & 7.19 & 34.33 & 9.51 & 48.35 & 40.73 & 62.48 & 15.57 & 5.72 \\
\hline \multirow{4}{*}{$\mathrm{G} I+\mathrm{G} I I+\mathrm{G} I V$} & B1 & 0.00 & 15.37 & 0.00 & 25.21 & 21.61 & 47.79 & 16.07 & 9.00 \\
\hline & B2 & 0.00 & 8.82 & 0.00 & 15.15 & 19.98 & 35.73 & 13.01 & 8.24 \\
\hline & B7 & 0.00 & 1.69 & 0.00 & 2.52 & 17.97 & 40.08 & 10.01 & 8.85 \\
\hline & $\mathrm{B} 10$ & 8.80 & 15.25 & 9.51 & 22.81 & 32.15 & 53.07 & 15.42 & 8.67 \\
\hline \multirow{4}{*}{$\mathrm{G} I+\mathrm{G} I I+\mathrm{G} I I I$} & B1 & 0.00 & 19.71 & 0.00 & 26.42 & 20.73 & 52.32 & 16.07 & 9.29 \\
\hline & B2 & 0.00 & 10.33 & 0.00 & 15.30 & 18.40 & 40.15 & 13.01 & 8.37 \\
\hline & B7 & 0.00 & 2.02 & 0.00 & 2.75 & 12.00 & 39.90 & 10.01 & 9.12 \\
\hline & B10 & 7.32 & 15.31 & 9.51 & 25.50 & 29.90 & 49.13 & 15.42 & 8.76 \\
\hline
\end{tabular}

Table 3 Sediment control effect under single structure condition 
Nat. Hazards Earth Syst. Sci. Discuss., doi:10.5194/nhess-2016-340, 2016

Manuscript under review for journal Nat. Hazards Earth Syst. Sci.

Published: 25 October 2016

(c) Author(s) 2016. CC-BY 3.0 License.

\section{(c) (i)}

Natural Hazards

and Earth System

Sciences

Discussions

$\mathrm{R}^{2}=0.82$, shown in Fig 12.That is, $\lambda_{f k}$ also can be expressed by $D_{\mathrm{k}}$ and $d_{\mathrm{fk}}$ with a power relationship (Eq.11).

$\lambda_{f k}=1.177\left(\frac{D_{k}}{d_{f k}}\right)^{-1.603}$

(3) Total separation rate $\left(P_{\mathrm{tk}}\right)$

Total separated sediment $\left(m_{\mathrm{tk}}\right)$ may be divided into separated coarse sediments $\left(m_{\mathrm{ck}}\right)$ and separated fine sediments $\left(m_{\mathrm{fk}}\right)$,

5 where the latter are smaller than $D_{\mathrm{k}}$ such that the total separation rate can be expressed asEq.13

$$
P_{t k}=\frac{m_{t k}}{M_{k}}=\frac{m_{c k}+m_{f k}}{M_{k}}=P_{c k}+P_{f k}=\lambda_{c k} \cdot f_{c k}+\lambda_{f k} \cdot\left(100-f_{c k}\right)
$$

Combining Eq.8 and Eq.11 in Eq. 13, $P_{t k}$ can be written as Eq.14

$$
P_{t k}=0.771 f_{c k}+1.177\left(\frac{D_{k}}{d_{f k}}\right)^{-1.603}\left(100-f_{c k}\right)
$$

In order to verify the precision of Eq.14, the resulting calculated values of $P_{\mathrm{tk}}$ were compared to measured values (Table

103 ).Figure 13 shows that they conformed well with each other with an $\mathrm{R}^{2}=0.900$. The average relative error is $14.8 \%$, which is acceptable from the perspective of engineering design. For simplicity, $P_{t k}$ can be further written as Eq.15:

$$
P_{t k}=f_{c k}+\left(\frac{D_{k}}{d_{f k}}\right)^{-1.603}\left(100-f_{c k}\right)
$$

Again, the calculated values agreed well with measured ones with ${ }^{2}=0.874$.The average relative error is $11.5 \%$, which is an improvement

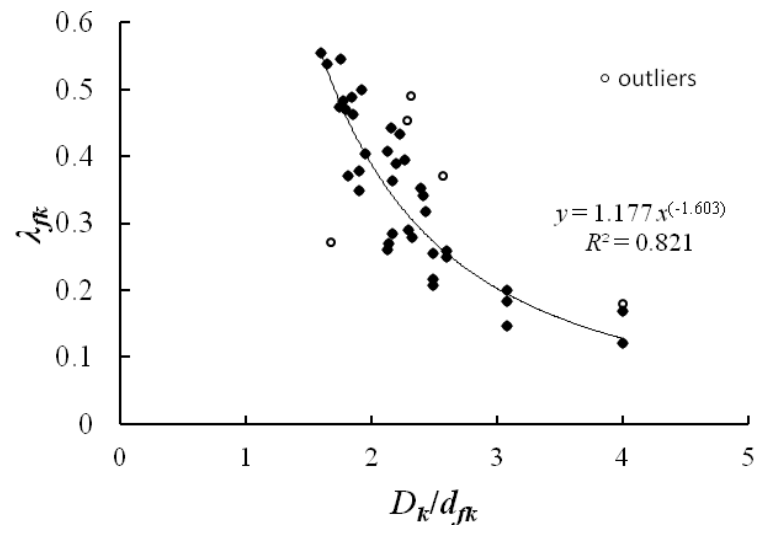

Figure12 Relationship between $\lambda_{f k}$ and $D_{k} / d_{f k}$

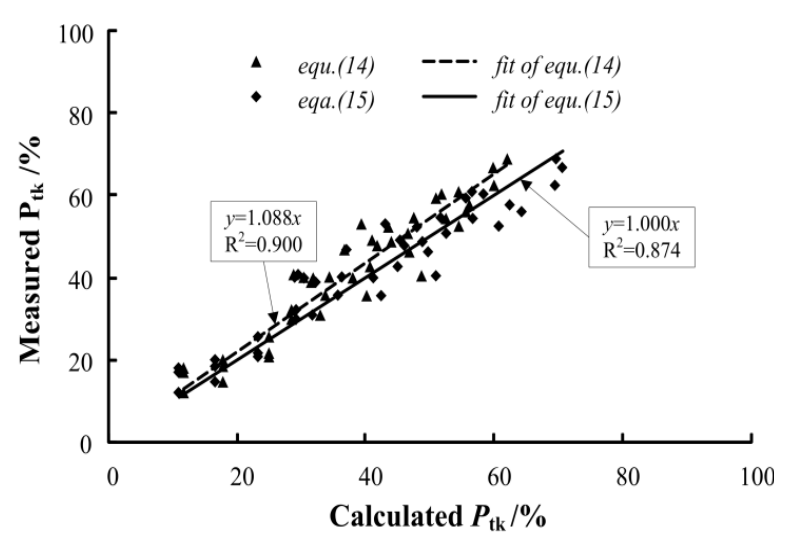

Figure13 2 Verification of $\boldsymbol{P}_{t k}$ 
Nat. Hazards Earth Syst. Sci. Discuss., doi:10.5194/nhess-2016-340, 2016

Manuscript under review for journal Nat. Hazards Earth Syst. Sci.

Published: 25 October 2016

(c) Author(s) 2016. CC-BY 3.0 License.
Natural Hazards 웅 and Earth System Sciences

Discussions (c) (i)

\section{M-HWSS System conditions}

From the results of single structure conditions, extrapolation can be made for the M-HWSS system conditions. Total coarse separation ratio $\left(\lambda_{c}(\mathrm{k})\right)$ and total separation rate $P_{\mathrm{t}}(\mathrm{k})$ for the former k structures may be written as Eq.16 and Eq. 17respectively:

$$
\lambda_{c}(k)=\frac{P_{c}(k)}{f_{o c}(k)},(k=1,2, \ldots, n)
$$

$$
P_{t}(k)=f_{o c}(k)+k^{2} \times\left(\sum_{j=1}^{k} \frac{D_{j}}{d_{o f}(j)}\right)^{(-1.60)} \times\left(100-f_{o c}(k)\right),(k=1,2, \ldots, n)
$$

Where, $f_{o c}(\mathrm{k})$ is the cumulative frequency distribution of the coarse fractions in the original input material; $d_{o f}(k)$ is the arithmetic mean diameter of the fine fractionsin the original input material.

\begin{tabular}{|c|c|c|c|c|c|c|c|c|c|c|c|}
\hline $\begin{array}{l}\text { Structure } \\
\text { combination }\end{array}$ & $\begin{array}{l}\text { Material } \\
\text { code }\end{array}$ & $\begin{array}{l}P_{t}(2) \\
(\%)\end{array}$ & $\begin{array}{l}P_{t}(3) \\
(\%)\end{array}$ & $\begin{array}{l}P_{c}(2) \\
(\%)\end{array}$ & $\begin{array}{l}P_{c}(3) \\
(\%)\end{array}$ & $\begin{array}{l}f_{o c}(1) \\
(\%)\end{array}$ & $\begin{array}{l}f_{o c}(2) \\
(\%)\end{array}$ & $\begin{array}{l}f_{o c}(3) \\
(\%)\end{array}$ & $\begin{array}{l}d_{o f}(1) \\
\mathrm{mm}\end{array}$ & $\begin{array}{l}d_{o f}(2) \\
\mathrm{mm}\end{array}$ & $\begin{array}{l}d_{o f}(3) \\
\mathrm{mm}\end{array}$ \\
\hline \multirow{9}{*}{$\mathrm{G} I I+\mathrm{G} I I I+\mathrm{G} I V$} & B1 & 81.48 & 87.79 & 57.29 & 79.97 & 32.53 & 60.00 & 79.83 & 9.56 & 5.83 & 3.50 \\
\hline & $\mathrm{B} 2$ & 72.74 & 80.43 & 46.37 & 71.10 & 20.61 & 47.29 & 71.87 & 8.84 & 5.73 & 3.50 \\
\hline & B3 & 75.66 & 80.49 & 48.51 & 68.55 & 27.92 & 55.28 & 79.91 & 9.23 & 5.70 & 3.50 \\
\hline & B4 & 63.60 & 75.96 & 29.79 & 59.04 & 10.18 & 35.41 & 70.99 & 8.31 & 5.70 & 3.50 \\
\hline & B5 & 79.21 & 87.11 & 41.18 & 75.75 & 10.16 & 42.49 & 82.19 & 9.41 & 6.26 & 3.50 \\
\hline & B6 & 83.30 & 91.03 & 56.64 & 82.36 & 21.83 & 59.51 & 88.06 & 10.50 & 6.32 & 3.50 \\
\hline & B7 & 66.84 & 75.51 & 33.28 & 62.67 & 3.71 & 39.76 & 74.33 & 9.28 & 5.98 & 3.50 \\
\hline & B8 & 76.70 & 83.68 & 48.55 & 73.61 & 25.20 & 49.96 & 76.25 & 8.71 & 5.60 & 3.50 \\
\hline & B9 & 59.02 & 81.54 & 38.84 & 73.11 & 17.87 & 48.59 & 81.53 & 9.41 & 6.06 & 3.50 \\
\hline \multirow{4}{*}{$\mathrm{G} I+\mathrm{G} I I I+\mathrm{G} I V$} & $\mathrm{~B} 1$ & 75.29 & 85.45 & 53.28 & 73.60 & 0.00 & 60.00 & 79.83 & 16.07 & 5.48 & 3.50 \\
\hline & $\mathrm{B} 2$ & 62.47 & 79.47 & 39.38 & 67.74 & 0.00 & 47.29 & 71.87 & 13.20 & 5.73 & 3.50 \\
\hline & B7 & 64.87 & 79.73 & 32.57 & 65.05 & 0.00 & 39.76 & 74.33 & 10.01 & 5.80 & 3.50 \\
\hline & $\mathrm{B} 10$ & 77.76 & 82.92 & 52.04 & 71.64 & 9.51 & 60.35 & 83.12 & 15.57 & 5.80 & 3.50 \\
\hline \multirow{4}{*}{$\mathrm{G} I+\mathrm{G} I I+\mathrm{G} I V$} & B1 & 59.07 & 75.58 & 24.81 & 66.57 & 0.00 & 32.53 & 79.83 & 16.07 & 9.36 & 3.50 \\
\hline & B2 & 41.60 & 68.91 & 15.55 & 58.43 & 0.00 & 20.61 & 71.87 & 13.01 & 8.60 & 3.50 \\
\hline & B7 & 50.85 & 72.42 & 3.03 & 59.66 & 0.00 & 3.71 & 74.33 & 10.01 & 9.24 & 3.50 \\
\hline & $\mathrm{B} 10$ & 68.16 & 82.34 & 32.15 & 70.26 & 9.51 & 37.28 & 79.66 & 15.42 & 8.96 & 3.50 \\
\hline \multirow{4}{*}{$\mathrm{G} I+\mathrm{G} I I+\mathrm{G} I I I$} & $\mathrm{~B} 1$ & 57.52 & 80.31 & 27.21 & 52.11 & 0.00 & 32.53 & 60.00 & 16.07 & 9.36 & 5.48 \\
\hline & $\mathrm{B} 2$ & 51.16 & 71.88 & 16.56 & 41.27 & 0.00 & 20.61 & 47.29 & 13.01 & 8.60 & 5.36 \\
\hline & B3 & 45.12 & 72.19 & 3.07 & 34.03 & 0.00 & 3.71 & 39.76 & 10.01 & 9.24 & 5.80 \\
\hline & B4 & 49.86 & 78.40 & 30.13 & 51.03 & 9.51 & 37.28 & 60.35 & 15.42 & 8.96 & 5.45 \\
\hline
\end{tabular}

Table 4 Sediment control effect under M-HWSS system conditions

Note: $P_{\mathrm{c}}(1)$ and $P_{\mathrm{t}}(1)$ are equal to $P_{\mathrm{c} 1}$ and $P_{\mathrm{t} 1}$ which are listed in table 3 
Nat. Hazards Earth Syst. Sci. Discuss., doi:10.5194/nhess-2016-340, 2016

Manuscript under review for journal Nat. Hazards Earth Syst. Sci.

Published: 25 October 2016

(C) Author(s) 2016. CC-BY 3.0 License.

\section{(c) (i)}

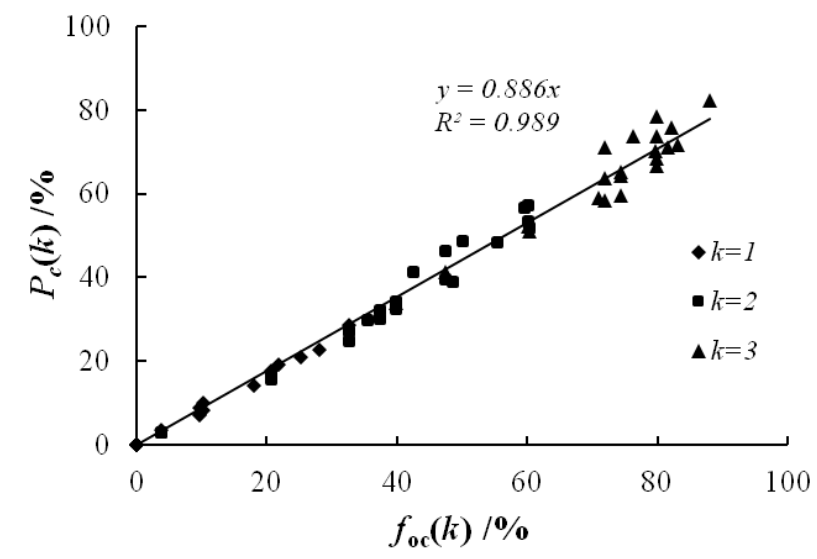

Figure14 Relationship between $P_{c}(k)$ with $f_{o c}(k)$
Natural Hazards

and Earth System

Sciences

Discussions

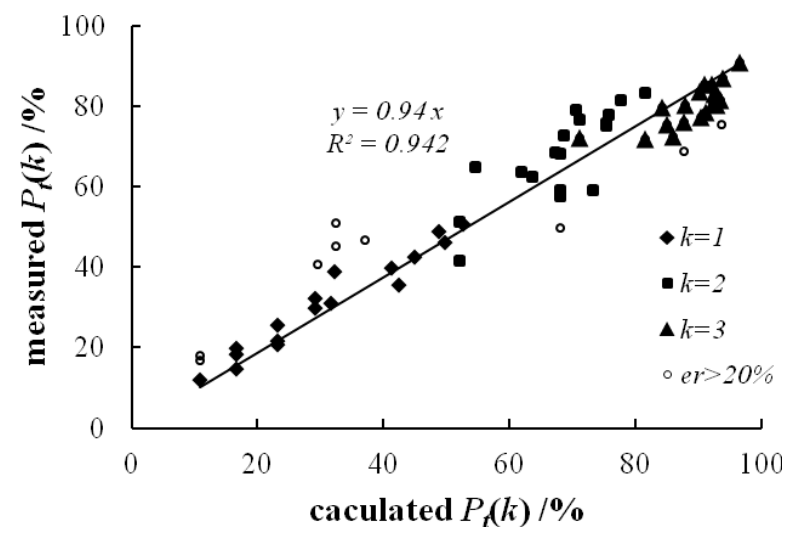

Figure15 Verification of $\boldsymbol{P}_{\boldsymbol{t}}(\mathbf{k})$

The measured values of $P_{\mathrm{c}}(\mathrm{k}), P_{\mathrm{t}}(\mathrm{k})$ are listed in Table 4 while $f_{o c}(\mathrm{k})$ and $d_{o f}(k)$ were calculated according to original material composition listed in Table 1. The calculated values of $P_{\mathrm{t}}(\mathrm{k})$ can be derivedthroughEq.17.Regression analysis, using the whole dataset of $P_{\mathrm{t}}(\mathrm{k})$ and $f_{\mathrm{oc}}(\mathrm{k})(\mathrm{k}=1,2,3)$, produced an average coarse separation ratio for the M-HWSS $\left(\lambda_{c}(\mathrm{k})\right)$ of 0.889 with $\mathrm{R}^{2}=0.988$, as shown in Fig. 14. Comparing this value with that of a single structure where $\lambda_{c k}=0.771$, demonstrates that the M-HWSS system significantly improves the coarse debris separation efficiency.

Figure 15 illustrates that calculated $P_{\mathrm{t}}(\mathrm{k})$ vales are slightly larger than the measured ones. The relative error of each $P_{\mathrm{t}}(\mathrm{k})\left(\mathrm{e}_{\mathrm{r}}\right)$ ranges from $0.23 \%$ to $40 \%$, with a mean of $12.24 \%$. By excluding those values with $\mathrm{e}_{\mathrm{r}}>20 \%$, the measured values are 0.94 times the calculated values with $\mathrm{R}^{2}=0.942$. The modified $e_{r}$ is $9.17 \%$, which falls in the rational accepted category for engineering design.

\section{Sediment separation under different structure configurations}

\section{System stability in sediment control}

Although only 3-HWSS systems were used in the experiments, the analysis may be expanded to three levels as 1HWSS (that is, single structure) (GI, GII), 2-HWSS (GII+GIII,GI+GII,GI+GIII) and 3-HWSS respectively. The corresponding total sediment separation rates $P_{\mathrm{t}}(\mathrm{k})$ under these configurations are shown in Table 3 and table 4.

A paired comparison method was used to evaluate system stability at different levels. The absolute variations of $P_{t}(\mathrm{k})\left(\Delta P_{\mathrm{t}}(\mathrm{k})\right)$ was used as an indicator.Fig.16 illustrates the $\Delta P_{\mathrm{t}}(\mathrm{k})$ under the same debris flow conditionsfor different system levels. $\Delta P_{\mathrm{t}}(1)$ ranged from $11 \%$ to $28 \%$ with most greater than $15 \%, \Delta P_{\mathrm{t}}(2)$ ranged from $6 \% \sim 26 \%$ with $70 \%$ greater than $15 \%$, and $\Delta P_{\mathrm{t}}(3) \mathrm{s}$ are all less than $12 \%$. Thus, from the perspective of total sediment separation rate, a significant improvement of system stability is achieved through an increase in the number of structures within a system. With a 3-HWSS system, the variability of sediment control effects lessens, although configurations are different for the same debris flow condition. It is suggested that a M-HWSS system has better risk resistance ability under differing sediment composition and magnitude 
Nat. Hazards Earth Syst. Sci. Discuss., doi:10.5194/nhess-2016-340, 2016

Manuscript under review for journal Nat. Hazards Earth Syst. Sci.

Published: 25 October 2016

(c) Author(s) 2016. CC-BY 3.0 License.

(c) (i)

conditions in debris flows. The variability of sediment control effects also suggests that a three-structure system is superior to two-structure system in accommodating to variable natural situations.

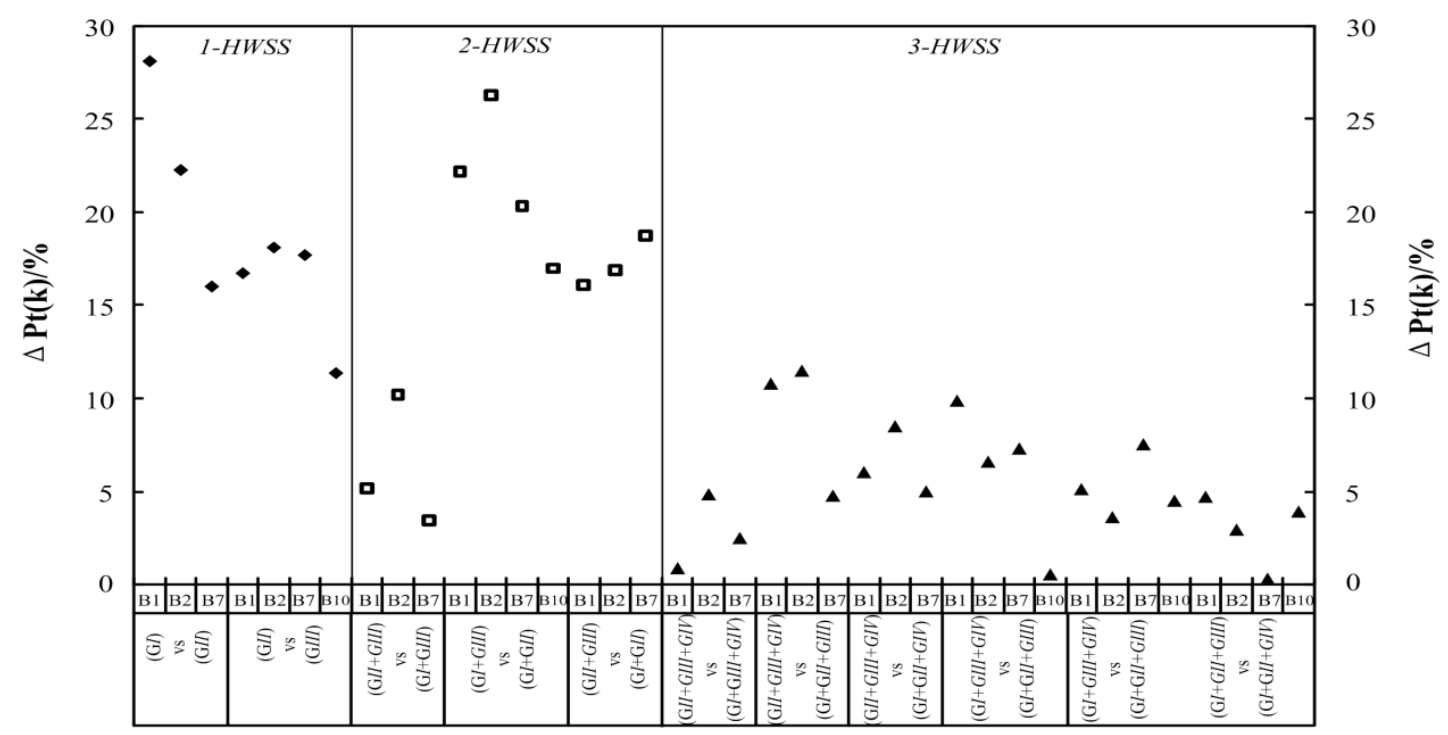

Figure 16 Variation of $\boldsymbol{P}_{t}(\mathbf{k})$ within different structure combination by paired comparison

\section{Under 1-HWSS system, $\mathrm{k}=1$, the absolute variations of $P_{t}(\mathrm{k})$ is $\Delta P_{\mathrm{t}}(1)$; under 2 -HWSS system, $\mathrm{k}=2$, the absolute variations of $P_{t}(k)$ is $\Delta P_{t}(2) ; \Delta P_{t}(3)$ demonstrates the absolute variations of 3-HWSS system.}

\section{The synergetic effect among structures}

Although the 3-HWSSsystemgenerally shows higher risk resistance stability, there are differences among different structure configurations. In order to understand the synergetic work of the M-HWSS system, sediment control effects for every structure must be analyzed. The total sediment control effect $\left(P_{\mathrm{tk}}\right)$ and the effective separation rate $\left(P_{\mathrm{ek}}\right)$ provide the basis for comparing different structure configurations. The effective separation rate $P_{\mathrm{ek}}$ is defined as the ratio between the separated coarse sediment and the total separated sediment and can be calculated by $P_{\mathrm{ck}} / P_{\mathrm{tk}}$. It reveals the amount of coarse sediment a structure can separate among the total separated sediments. $P_{\mathrm{ek}}$ values for every structure in the four 3-HWSS systems used in the experiments are listed in Table 5.

Again, a paired comparison method was used to provide an analysis of the four 3-HWSS systems and their synergetic effects.Figure 17 shows the total separation rate $P_{\mathrm{tk}}$ and effective separation rate $P_{\mathrm{ek}}$ for each structure in different M-HWSS systems with the same debris flow conditions.

(1) $\mathrm{G} I I+\mathrm{G} I I I+\mathrm{G} I V$ vs. $\mathrm{G} I+\mathrm{G} I I I+\mathrm{G} I V$ 
Nat. Hazards Earth Syst. Sci. Discuss., doi:10.5194/nhess-2016-340, 2016

Manuscript under review for journal Nat. Hazards Earth Syst. Sci.

Published: 25 October 2016

(C) Author(s) 2016. CC-BY 3.0 License.
Natural Hazards

and Earth System

Sciences

Discussions

(c) (P)

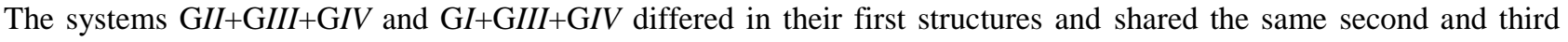
structures. Comparing the first structures, GII and GI, the sediment separation rates of $P_{t 1}$ and $P_{\mathrm{e} 1}$ are better for the former than the latter. For GI, $P_{\mathrm{e} 1}=0$ (i.e. no coarse sediment separation) with the debris flow input sediment of B1, B2 and B7 because the grid opening width of $\mathrm{G} I(40 \mathrm{~mm})$ is larger than the maximum grain size of the input sediment..Similar results are

5 shown for the first structures in $\mathrm{G} I+\mathrm{G} I I+\mathrm{G} I V$ and $\mathrm{G} I+\mathrm{G} I I+\mathrm{G} I I I$. Despite the non-zero $P_{\mathrm{e} 1}\left(P_{\mathrm{e} 1=17.6 \%)}\right.$ obtained for the case of B10, it is too low to be satisfactory. The control effects of the upstream structures influence those downstream as shown inthe two configurations with GIII second structures. The effective separation ratio $\left(P_{\mathrm{e} 2}\right)$ indicates that GIII following GI is more effective than GIII following GII. GI was less effective in sediment separation than GII, leaving more sediment to be separated by the following GIII structure. The total separation rate $\left(P_{\mathrm{t} 2}\right)$ presented a similar result. The synergy control effect

10 of $\mathrm{G} I I+\mathrm{G} I I I$ is superior to $\mathrm{G} I+\mathrm{G} I I I$ as reflected in $P_{\mathrm{t}}(2)$.Following second structure, the control effects of the third structure

Table 5 the effective separation rate for single structures in the 3-HWSS configurations

\begin{tabular}{|c|c|c|c|c|c|c|c|}
\hline \multirow{2}{*}{$\begin{array}{l}\text { System } \\
\text { combination }\end{array}$} & \multirow{2}{*}{$\begin{array}{l}\text { Sediment } \\
\text { code }\end{array}$} & \multicolumn{2}{|c|}{$1^{\text {th }}$ structure } & \multicolumn{2}{|c|}{$2^{\text {th }}$ structure } & \multicolumn{2}{|c|}{$3^{\text {th }}$ structure } \\
\hline & & $f_{\mathrm{c} 1}$ & $P_{\mathrm{e} 1}$ & $f_{\mathrm{c} 2}$ & $P_{\mathrm{e} 2}$ & $f_{\mathrm{c} 3}$ & $P_{\mathrm{e} 3}$ \\
\hline \multirow{9}{*}{$\mathrm{G} I I+\mathrm{G} I I I+\mathrm{G} I V$} & W1 & 32.53 & 56.53 & 35.80 & 50.18 & 22.93 & 54.33 \\
\hline & W2 & 20.61 & 44.59 & 26.48 & 45.67 & 18.10 & 53.71 \\
\hline & W3 & 27.92 & 46.32 & 35.44 & 42.33 & 57.06 & 58.90 \\
\hline & W4 & 10.18 & 21.09 & 19.93 & 26.54 & 50.68 & 58.40 \\
\hline & W5 & 10.16 & 21.69 & 20.82 & 30.16 & 53.34 & 61.75 \\
\hline & W6 & 21.83 & 41.18 & 42.20 & 53.49 & 61.19 & 73.09 \\
\hline & W7 & 3.71 & 11.17 & 27.69 & 35.83 & 47.31 & 54.33 \\
\hline & W8 & 25.20 & 49.03 & 29.00 & 44.73 & 29.84 & 53.71 \\
\hline & W9 & 17.87 & 40.07 & 33.49 & 50.45 & 65.58 & 73.09 \\
\hline \multirow{4}{*}{$\mathrm{G} I+\mathrm{G} I I I+\mathrm{G} I V$} & $\mathrm{~W} 1$ & 0.00 & 0.00 & 52.74 & 65.44 & 47.32 & 53.73 \\
\hline & $\mathrm{W} 2$ & 0.00 & 0.00 & 44.32 & 62.53 & 39.61 & 52.03 \\
\hline & W7 & 0.00 & 0.00 & 36.04 & 47.44 & 49.08 & 53.57 \\
\hline & W10 & 9.51 & 17.65 & 48.35 & 54.96 & 63.17 & 49.81 \\
\hline \multirow{4}{*}{$\mathrm{G} I+\mathrm{G} I I+\mathrm{G} I V$} & $\mathrm{~W} 1$ & 0.00 & 0.00 & 25.21 & 32.16 & 58.96 & 65.84 \\
\hline & $\mathrm{W} 2$ & 0.00 & 0.00 & 15.15 & 24.69 & 52.70 & 67.21 \\
\hline & W7 & 0.00 & 0.00 & 2.52 & 4.23 & 57.87 & 63.84 \\
\hline & W10 & 9.51 & 27.37 & 22.81 & 28.74 & 54.52 & 56.14 \\
\hline \multirow{4}{*}{$\mathrm{G} I+\mathrm{G} I I+\mathrm{G} I I I$} & $\mathrm{~W} 1$ & 0.00 & 0.00 & 26.42 & 37.67 & 33.59 & 26.52 \\
\hline & $\mathrm{W} 2$ & 0.00 & 0.00 & 15.30 & 25.73 & 22.61 & 24.23 \\
\hline & W7 & 0.00 & 0.00 & 2.75 & 5.07 & 21.73 & 22.97 \\
\hline & W10 & 9.51 & 24.48 & 25.50 & 31.16 & 36.70 & 26.81 \\
\hline
\end{tabular}


Nat. Hazards Earth Syst. Sci. Discuss., doi:10.5194/nhess-2016-340, 2016

Manuscript under review for journal Nat. Hazards Earth Syst. Sci.

Published: 25 October 2016

(c) Author(s) 2016. CC-BY 3.0 License.

$(\mathrm{GIV})$ in both configurations tend to be similar, and the overall control effect of the two 3-HWSS systems reached a same level (see $\left.P_{\mathrm{t}}(3)\right)$. The combination of $\mathrm{G} I I+\mathrm{G} I I I+\mathrm{G} I V$ is generally superior to $\mathrm{G} I+\mathrm{G} I I I+\mathrm{G} I V$ from both total amount of sediment control effect and effective separation effect.
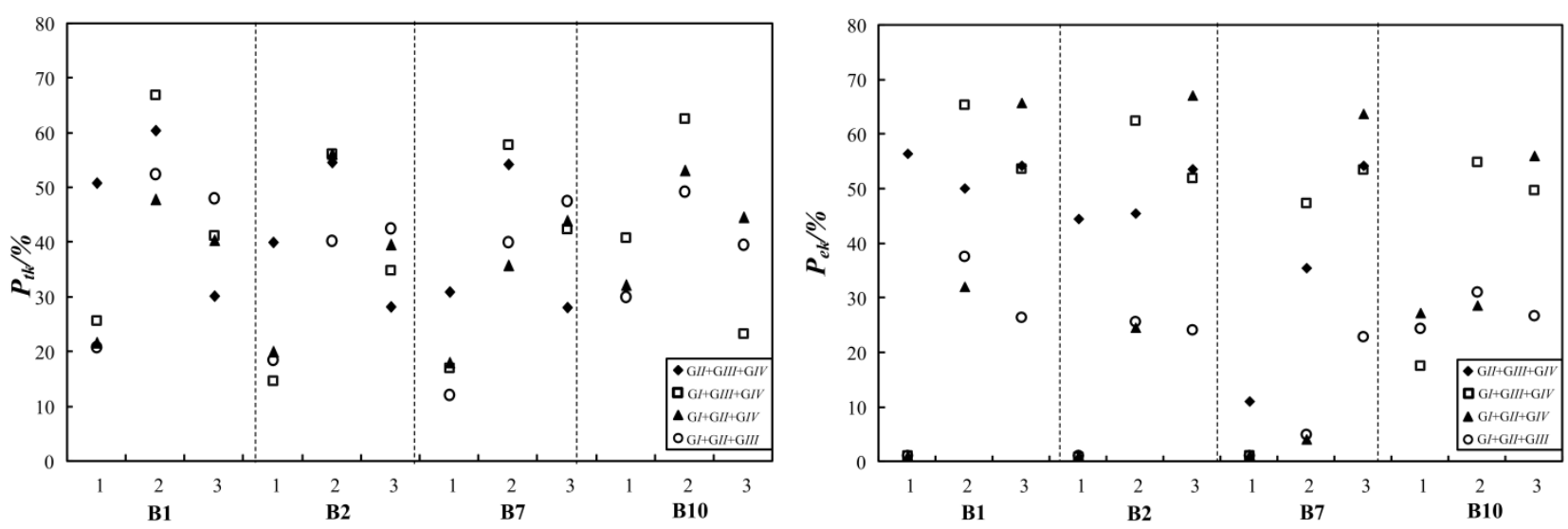

Figure 17 A comparison of sediment control effect for the same input sediment under differing structure configurations(left: $\boldsymbol{P}_{\mathrm{tk}}$; right: $P_{\text {ek }}$ ) Note: in $\mathrm{x}$-coordinate, B1,B2,B7 and B10 are the input sediment material code, which represents debris flow condition.

The number of 1,2 and 3 represents the herringbone structure position in a 3-HWSS system.1 indicates the first (upstream) structure, 2 the second (middle) structure and 3 the third (downstream) structure..

(2) $\mathrm{G} I+\mathrm{G} I I I+\mathrm{G} I V$ vs. $\mathrm{G} I+\mathrm{G} I I+\mathrm{G} I V$

In these structure configurations, the second structure, GIII, performed better than its equivalent, GII, for all the cases, producing higher $P_{\mathrm{t} 2}$ and $P_{\mathrm{e} 2}$ valuesas shown in Fig. 17. This also may be explained by the relationship of $P_{\mathrm{ek}}$ with $f_{\mathrm{ck}}$. In both configurations, after passing through GI the discharged sediment should have similar grain size distributions. However, the smaller grid opening width of GIII results a higher $f_{\mathrm{ck}}$, producing higher $P_{\mathrm{ek}}$ and $P_{\mathrm{tk}}$ values.

Influenced by the different control effect of the second structures, the control effects $\left(P_{\mathrm{e} 3}\right)$ of the third $G I V$ structures differs.. The effective separation rate for GIV following GII is better than that following GIII. This too may be explained by the lesser performance of GII. The total separation rate $\left(P_{\mathrm{t} 3}\right)$ is similar in both configurations and the ultimate synergy effect , $P_{\mathrm{t}}(3)$, is better in $\mathrm{G} I+\mathrm{G} I I I+\mathrm{G} I V$ than in $\mathrm{G} I+\mathrm{G} I I+\mathrm{G} I V$. The combination of $\mathrm{G} I+\mathrm{G} I I+\mathrm{G} I V$ is superior to $\mathrm{G} I+\mathrm{G} I I+\mathrm{G} I V$ for both total sediment control and effective sediment separation.

\section{(3) $\mathrm{G} I+\mathrm{G} I I+\mathrm{G} I V$ vs. $\mathrm{G} I+\mathrm{G} I I+\mathrm{G} I I I$}

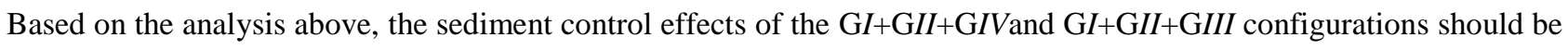
lower than in the previous two systems due to the lower effectiveness of the GII structure. Of the differing last structures, GIV should produce a higher effective separation rate $\left(P_{e 3}\right)$ as its smaller grid opening width produces a higher $f_{\mathrm{ck}}$ with similar input material. Figure 17 confirms this prediction. Indeed, GIV in GI+GII+GIV produces the highest effective separation rate because of the relatively low control effect of the upstream structures and its small grid opening width.The ultimate total separation rate $P_{\mathrm{t}}(3)$ for the two configurations is approximately the same. 
Nat. Hazards Earth Syst. Sci. Discuss., doi:10.5194/nhess-2016-340, 2016

Manuscript under review for journal Nat. Hazards Earth Syst. Sci.

Published: 25 October 2016

(c) Author(s) 2016. CC-BY 3.0 License.

(c) (i)

In summary, the four systems used in the experiments shared a sequence of synergetic effects such that $\mathrm{G} I I+\mathrm{G} I I I+\mathrm{G} I V>\mathrm{G} I+\mathrm{G} I I I+\mathrm{G} I V>\mathrm{G} I+\mathrm{G} I I+\mathrm{G} I V>\mathrm{G} I+\mathrm{G} I I+\mathrm{G} I I I$.

Preliminary guidelines for the design of a M-HWSS system

arising from the experiments and analyses are:

(1) The grid opening width in a structure should be smaller than the maximum grain size in the input sediment to have an acceptable coarse fraction separation effect. Actually, the effective separation rate $\left(P_{\mathrm{ek}}\right)$ relates with the coarse

10 cumulative frequency distribution of the input sediment.

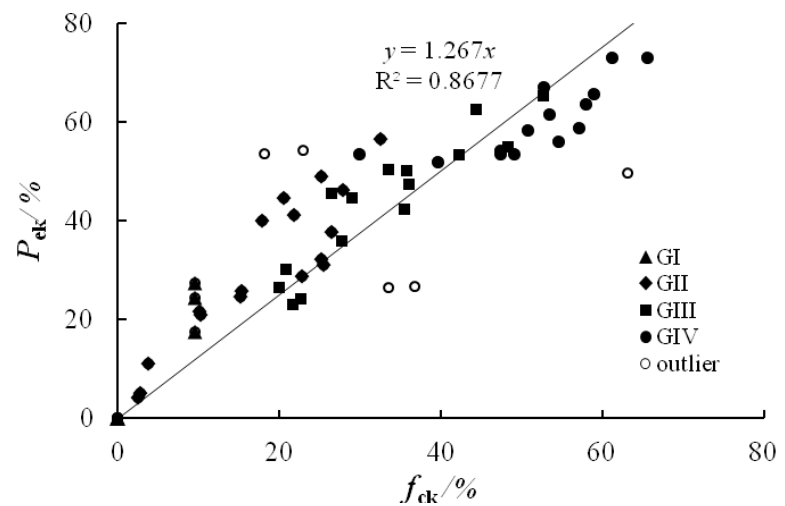

Figure18 Relationship between $P_{\text {ek }}$ and $f_{\text {ck }}$ Figure 18, based on Table 5, shows the relationship between the coarse cumulative frequency distribution of input sediment $\left(f_{\mathrm{ck}}\right)$ and $P_{\mathrm{ek}}$ as described by a linear function (Eq.18).

$$
P_{e k}=1.267 f_{c k} \cong 1.3 f_{c k}
$$

Given the effective separation rates produced by $\mathrm{G} I I+\mathrm{G} I I I+\mathrm{G} I V,(20 \sim 60 \%)$, it is suggested that opening width may be set

15 at the percentile of $d_{50} \sim d_{84}$ of the input sediment grain size distribution by back-calculationinEq. 18 .

(2) For a 3-HWSS or larger system, the first structure (upstream)should be designed to separate large caliber sediment (boulders) and debris that have high impact pressures in debris flows. The middle structure design should separate most of the remaining harmful debris (cobbles and large pebbles) and reduce the debris flow discharge magnitude. The last structure (downstream) should be designed to complement and enhance the sediment control effect such that a debris flow is transformed into fine sediment-laden flow as much as possible.

\section{Conclusions}

A multiple herringbone water-sediment separation structure (M-HWSS) system was developed and tested for improved debris flow mitigation. This builds upon the understanding that multiple debris and sediment control structures in known debris flow channels are most effective in mitigating the hazardous impacts of debris flows. Prior research also has demonstrated the effectiveness of a single herringbone water-sediment separation structure (HWSS) in debris flow mitigation through separation of water and sediment. Critical to the effectiveness of a M-HWSS system is an understanding of how the multiple structures work together to reduce debris flow impact pressures and total discharge. To reach that objective, a series of laboratory model tests were conducted using various configurations of multiple structures. Two parameters, the sediment separation rate $\left(P_{\mathrm{t}}\right)$ and the coarse separation ratio $\left(\lambda_{c}\right)$ were used to assess the effectiveness of theM-HWSS systems in sediment control.

The results indicate that M-HWSS systems do perform better than single structures insediment control. Generally, the sorting of sediments may be improved by optimizing the structural parameters and increasing the number of structures. By 
Nat. Hazards Earth Syst. Sci. Discuss., doi:10.5194/nhess-2016-340, 2016

Manuscript under review for journal Nat. Hazards Earth Syst. Sci.

Published: 25 October 2016

(C) Author(s) 2016. CC-BY 3.0 License.
Natural Hazards 응

and Earth System

Sciences

Discussions

(c) (i)

separating coarse debris gradually, the mean grain size of discharged sediment decreases but after a certain number of structures, it remains approximately constant, suggesting that there is an optimum number of structures for multi-structure systems.. The grain size distribution of the input sediment and herringbone structure grid opening width were important factors that influenced the sediment control effect. With different debris flow input sediment, the control effect differed

5 within the same M-HWSS system, and vice versa. Preliminary relationships between sediment control effects and sediment grain size distribution and structure grid opening width were developed under both single structure and M-HWSS system conditions. These can be used for guidance in M-HWSS systems design.

Paired comparisons of the M-HWSS models used in the experiments provided a preliminary basis for optimum structure configuration. It is clear that the performance of the upstream structures strongly influences that of downstream

10 structures. The experimental results indicate that the grid opening width of successive structures in a system should be set at the $d_{50} \sim d_{84}$ percentile of the expected input sediment grain size distribution to achieve a $20 \sim 60 \%$ effective separation rate. Debris separation through successive structures should reduce impact pressures and total discharge, thus mitigating the most hazardous aspects of debris flow events.

\section{Acknowledgments}

This research was supported by the National Science and Technology Support Program (2011BAK12B00).The authors would like to thank Professor Cheng Zunlan of IMHE,CAS for her provision of grain size distribution data from a debris flow on the Zha-Mo road in Tibet, China.

\section{References}

Armanini A., Dellagiacoma F., Ferrari L.: from the check dam to the development of functional check dams. Fluvial Hydraulics of Mountain Regions, Lecture Notes on Earth Sciences, n37, Springer-Verlag,331-344. 10.1007/BFb0011200,1991

Armanini A., Dalr C. ,Larcher M.: Slit-Check Dams for Controlling Debris Flows and Mudflow.Disaster Mitigation of Debris Flows, Slope Failures and Landslides, by Universal Academy Press, Inc. / Tokyo, Japan. 141-148. 2006.

Blott S.J. and Pye K.: GRADISTAT: a grain size distribution and statistics package for the analysis of unconsolidated sediments. Earth Surface Processes andLandforms 26: 1237-1248, doi: 10.1002/esp.261, 2001

Bunte S.K., Abt S.R.: Sampling surface and subsurface particle-size distributions in wadeable gravel-and cobble-bed streams for analyses in sediment transport, hydraulics, and streambed monitoring. Gen. Tech. Rep. RMRS-GTR-74. Fort Collins,CO: U.S. Department of Agriculture, Forest Service, Rocky Mountain Research Station. 428 p.2001.

Fei X., Kang Z.,Wang Y.: Effect of fine grain and debris flow slurry bodies on debris flow motion. Mountain Research 9(3):143-152. 1991. (in Chinese) 
Nat. Hazards Earth Syst. Sci. Discuss., doi:10.5194/nhess-2016-340, 2016

Manuscript under review for journal Nat. Hazards Earth Syst. Sci.

Published: 25 October 2016

(C) Author(s) 2016. CC-BY 3.0 License.
Natural Hazards

and Earth System

Sciences

Discussions

Folk R. L.: Brazos river bar, a study in the significance of grain size parameter. Jour Sediment Petrol, 27(1):3-26. 1957.

Friedman G.M. and Johnson K.G.: Exercises in Sedimentology. Wiley: New York, doi: 10.1306/74D70646-2B21-11D7-

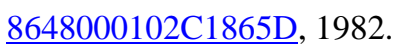

Gonda, Y.: Function of a debris flow brake. International Journal of Erosion Control Engineering, 2(1): 15- 21,doi: 10.13101/ijece.2.15, 2009.

McManus J.: Grain size determination and interpretation. In Techniques in Sedimentology, Tucker M (ed.). Blackwell: Oxford.63-85, 1988.

Mizuyama T.: Structural Countermeasures for Debris Flow Disasters. International Journal of Erosion Control Engineering 1(2): 38-43, doi: 10.13101/ijece.1.38, 2008.

10 Mouri G., Golosov V., Chalov S., et al.: Assessing the effects of consecutive sediment-control dams using a numerical hydraulic experiment to model river-bed variation. Catena 104: 174 -185, doi: 10.1016/j.catena.2012.11.008,2013.

Namgyun K.H., Nakagawa K., Kawaike K., et al.: A study on debris flow outflow discharge at a series of sabo dams. J. JSNDS, 33: 43-52, doi: 10.2208/jscejhe.69.I 97 ,2014.

Osti R., Egashira S.: Method to improve the mitigative effectiveness of a series of check dams against debris flows. Hydrol. Processes, 22, 4986- 4996, doi: 10.1002/hyp.7118,2008.

Salzmann H.: Debris flow mitigation by means of flexible barriers. Proceedings 14th Southeast Asia Geotechnical Conference, Hongkong, 2001)

Shu A., Zhang Z., Wang L.,et al.: Method for determining the critical grain size of viscous debris flow based on energy dissipation principle. Journal of hydraulic engineering,38(3):257-263. doi:10.3321/j.issn:0559-9350.2008.03.001, 2008. (In Chinese)

Wehrmann H., H"ublJ., Holzinger G.: Classification of dams in torrential watersheds. Proceeding of Disaster Mitigation of Debris Flows, Slope Failures and Landslides, Universal Academy Press, Inc. / Tokyo, Japan. 829-838. 2006.

Xie T., Wei F., Yang H.,et al.: Optimal value of structural parameters in a new water-sediment separation structure for debris flow defense. Mountain Research.33 (1):116-122. doi:10.16089/j.cnki.1008-2786.000016, 2015.(In Chinese)

25 Xie T.,Xie X., Wei F., et al.: Applicability experiment of Herringbone Water-sediment Separation Structure for debris flow prevention. Journal of Hydraulic Engineering, 45(11):1-9, doi: 10. 13243 /j.cnki.slxb. 2014. 11. 000, 2014. (In Chinese)

XieT.,Yang H., Wei F., et al.: A new type debris flow water-sediment separation structure and its model test. Bulletin of Engineering Geology and the Environment, 73(4):947-958, doi: 10.1007/s10064-014-0585-9, 2014.

Xie X., Wei F., Xie T., et al.: Experimental Study on the Clogging and Deposition of Driftwood Flowing with Torrents behind Debris Dams, Journal of Mountain Science, 32(2):249-254, doi:10.3969/j.issn.1008-2786.2014.02.016, 2014. (In Chinese)

Xie X., Wei F., Yang H.,et al.: Herringbone Water-sediment Separation Structure Parameters Optimization Based on the Water-wood Separation Effect. Journal of Sichuan University (Engineering Science Edition).48(1):55-63, doi:10.15961/j.jsuese.2016.01.009, 2016. (In Chinese) 
Nat. Hazards Earth Syst. Sci. Discuss., doi:10.5194/nhess-2016-340, 2016

Manuscript under review for journal Nat. Hazards Earth Syst. Sci.

Published: 25 October 2016

(c) Author(s) 2016. CC-BY 3.0 License.

(c) (i)

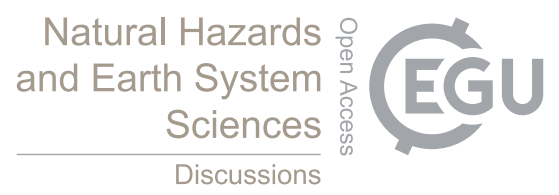

VanDine, D.F.: Debris flow control structures for forest engineering. Victoria, British Columbia: Research Branch, BC Ministry of Forests, Working Paper, 08/1996. 1996) 